\title{
Cutaneous Leishmaniasis in Algeria; Highlight on the Focus of M'Sila
}

\author{
Razika Benikhlef ${ }^{1,2, *}$, Karim Aoun ${ }^{2,3}$, Abdelkarim Boudrissa ${ }^{4}$, Meriem Ben Abid ${ }^{2}$, Kamel Cherif ${ }^{5}(0)$ \\ Wafa Aissi ${ }^{6}$, Souad Benrekta ${ }^{7}$, Said C. Boubidi ${ }^{1}$, Gerald F. Späth ${ }^{8}$, Aïda Bouratbine ${ }^{2}$, Denis Sereno ${ }^{9,10, *(1)}$ \\ and Zoubir Harrat ${ }^{1}$
}

check for updates

Citation: Benikhlef, R.; Aoun, K.; Boudrissa, A.; Ben Abid, M.; Cherif, K.; Aissi, W.; Benrekta, S.; Boubidi, S.C.; Späth, G.F.; Bouratbine, A.; et al. Cutaneous Leishmaniasis in Algeria; Highlight on the Focus of M'Sila. Microorganisms 2021, 9, 962. https://doi.org/10.3390/ microorganisms 9050962

Academic Editor:

Lorenzo Zammarchi

Received: 26 March 2021

Accepted: 21 April 2021

Published: 29 April 2021

Publisher's Note: MDPI stays neutral with regard to jurisdictional claims in published maps and institutional affiliations.

Copyright: (c) 2021 by the authors. Licensee MDPI, Basel, Switzerland. This article is an open access article distributed under the terms and conditions of the Creative Commons Attribution (CC BY) license (https:/ / creativecommons.org/licenses/by/ $4.0 /)$.
1 Laboratoire d'Eco-épidémiologie Parasitaire et Génétique des Populations, Route du Petit Staoueli, Institut Pasteur d'Algérie, Dely-Brahim 16047, Algeria; saidboubidi@yahoo.fr (S.C.B.); harrat_zoubir@yahoo.fr (Z.H.)

2 Laboratoire de Recherche "Parasitologie Médicale, Biotechnologies et Biomolécules", LR 20-IPT-06, Institut Pasteur de Tunis, Université Tunis El Manar, 13, Pl Pasteur BP 74, Tunis 1002, Tunisia; karim.aoun@pasteur.tn (K.A.); meriembenabid@gmail.com (M.B.A.); aida.bouratbine@pasteur.tn (A.B.)

3 Laboratoire d'Epidémiologie et d'Ecologie Parasitaires, Institut Pasteur de Tunis, 13, Pl Pasteur BP 74, Tunis 1002, Tunisia

4 Antenne de M'Sila, Institut Pasteur d'Algérie, M'sila 28000, Algeria; boudrissakarim@yahoo.fr

5 Département de Biologie, Université de M'Sila, BP 166, M'Sila 28000, Algeria; kamel.cherif@univ-msila.dz

6 Centre National pour la Promotion de la Transplantation d'Organes, Faculté de Médecine de Tunis, Université Tunis El Manar, Rue Jebel Lakdhar, Tunis 1006, Tunisia; wafa.aissi@fmt.utm.tn

7 Service d'Epidémiologie et de Médecine Préventive, Commune de Boussaâda, M'sila 280001, Algeria; souadbenrekta@gmail.com

8 Unité de Parasitologie Moléculaire et Signalisation (ParSig), Department of Parasites and Insect Vectors (PIV), Institut Pasteur/INSERM U1201, 25 Rue du Dr. Roux, 75015 Paris, France; gerald.spaeth@pasteur.fr

9 IRD, University of Montpellier, InterTryp, 34000 Montpellier, France

10 IRD, University of Montpellier, MiVeGec, 34000 Montpellier, France

* Correspondence: rbenikhlef@yahoo.fr (R.B.); denis.sereno@ird.fr (D.S.)

\begin{abstract}
Algeria ranks second after Afghanistan for the incidence of cutaneous leishmaniasis (CL) worldwide. Here, we report a 34-years retrospective analysis of CL in Algeria and focused on the most affected region, the M'Sila province. All 66 cutaneous isolates corresponded to Leishmania (L.) major. Our study of the sandfly and rodent fauna further highlighted the high density of Phlebotomus papatasi and additional phlebotomine species of medical importance, not previously identified in M'Sila. Wild rodents belonging to nine species were trapped in M'Sila, and Psammomys obesus and Meriones shawi were found infected by L. major. In addition, Leishmania infantum was isolated from two visceral leishmaniasis cases, one dog and its proven vectors (P. perniciosus, P. longicuspis, and P. perfiliewi) inventoried during the survey. The high incidence of CL in the M'Sila province is likely a consequence of the increase in minimum temperatures recorded that constitutes suitable conditions for establishing a high endemicity and leads to an explosive rise in leishmaniases cases in this region. A thorough investigation of the underlying risk factors is urgently needed to detect new cases earlier. All these would improve the preparedness to fight the disease.
\end{abstract}

Keywords: cutaneous leishmaniasis; epidemiology; Leishmania major; sandflies; rodents; M'Sila; Algeria

\section{Introduction}

Algeria ranks second after Afghanistan in cutaneous leishmaniasis (CL) incidence [1]. Initially confined in the high plateaus' steppe regions in the semi-arid and arid bioclimatic zones [2,3], CL has undergone a worrying geographic extension toward the north of Algeria [4]. Such an expansion also occurs in the Maghreb and the Middle East [1,5-7].

The province of M'Sila is located in Central-Eastern Algeria and is most affected by the disease, with nearly 90,000 cumulative cases recorded since 1982 [8]. Cutaneous leishmaniasis is first described in 1860 in Algeria [9] and 1924 in the Hodna basin [10]. 
Since the 1980s, the situation has become alarming, with about 3000 annual cases [11]. Zoonotic CL (ZCL), caused by L. major, is currently the only clinical form endemic in the region [12]. The wild rodents Psammomys (P). obesus and Meriones $(M)$. shawi are the primary reservoirs, and Phlebotomus $(P)$. papatasi the proven vector [13-15]. The province of $\mathrm{M}^{\prime} \mathrm{Sila}$ is an agro-pastoral area with 1.3 million inhabitants over $18,175 \mathrm{~km}^{2}$ [16]. It is located $240 \mathrm{~km}$ south-east of Algiers, in the country's highlands within the broad semi-arid and arid region of Hodna (Figure 1A,B). The Hodna region is a vast, steppe-like plain, silty in the North and sandy in the South, with four distinct areas, i.e., mountains, piedmont, lowland, and the Sebkha, a flooded grassland (76,000 hectares of bare clay) [17]. The hydro-geographic basin of Hodna is the most active focus of CL, with more than $75 \%$ of cases identified in this basin [18]. Seven provinces (M'Sila, Batna, Bordj-Bou Arreridj, Djelfa, Médéa, Bouira, and Sétif), belonging to the same noso-geographical region, are linked together by a tangled hydrographic network and a dense road network (Figure 1A,B). Biskra, the former and still active focus of ZCL, is only $190 \mathrm{~km}$ from M'Sila city (Figure 1A).

(A)

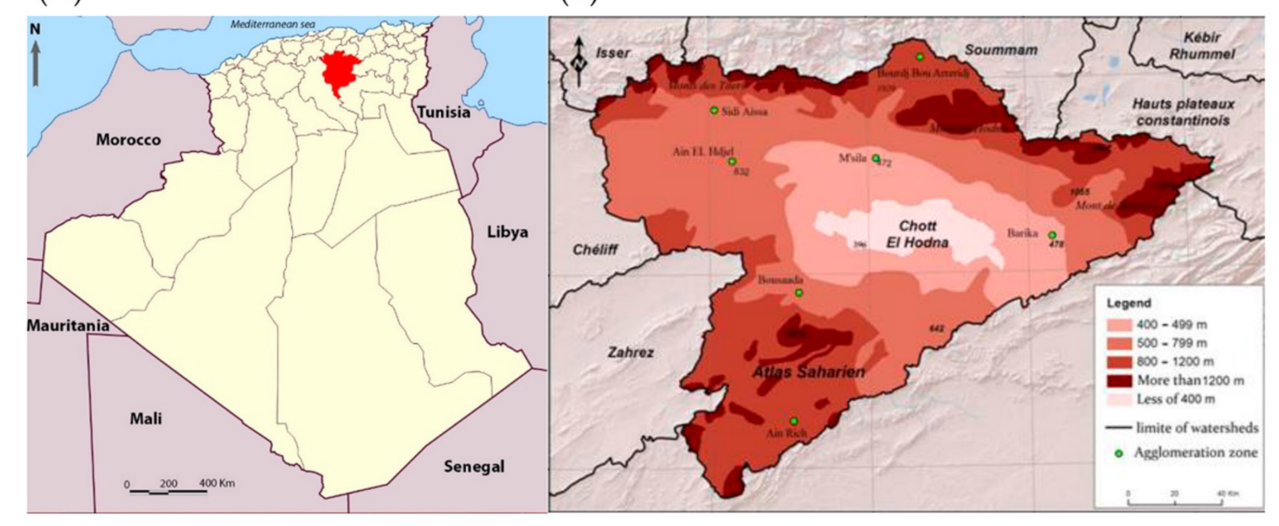

Figure 1. Geographic location of (A) the M'Sila province and (B) the salt-lake of Chott el Hodna [19].

Starting from a longitudinal survey on the incidence of CL cases from 1982 to 2020 in the M'Sila focus, we gathered data on the diversity of the phlebotomine sandfly and rodent fauna and ecological factors in this region. We put them in perspective with the overall CL epidemiological situation in Algeria. These analyses are helpful to improve future public health strategies aimed at controlling ZCL.

\section{Materials and Methods}

\subsection{Study Area and Study Design}

The province of $\mathrm{M}^{\prime}$ Sila locates between $35^{\circ} 18^{\prime}$ and $35^{\circ} 32^{\prime}$ North and $4^{\circ} 15^{\prime}$ and $5^{\circ} 06^{\prime}$ East, $240 \mathrm{~km}$ south-east of Algiers, in the country's highlands. Rainfall varies from $69 \mathrm{~mm}$ to $200 \mathrm{~mm}$ /year, and the average annual temperatures between $13^{\circ} \mathrm{C}$ and $23^{\circ} \mathrm{C}$, with extremes of $-5^{\circ} \mathrm{C}$ in winter to $46^{\circ} \mathrm{C}$ in summer [20]. The province encompasses 15 Daïras (districts), and the most populated one is M'Sila, a city followed by Boussaâda, called "the gateway to the Sahara" (Figure 2).

In the endemic foci of M'Sila, we collected data on ZCL incidence from 1982 to 2020 and other associated information, including clinical aspects of lesions, the dynamic and diversity of the phlebotomine, and the diversity of the wild rodent's population. In parallel, data on CL incidence in Algeria were computed for the 48 provinces of the country from 1982 to 2017 [8]. A phlebotomine fauna survey was carried out from 2003 to 2004 and in 2018 in various sites: stables, sheepfolds, gardens, rodent burrows, palm groves, crevices, and dwellings (Table 1). 


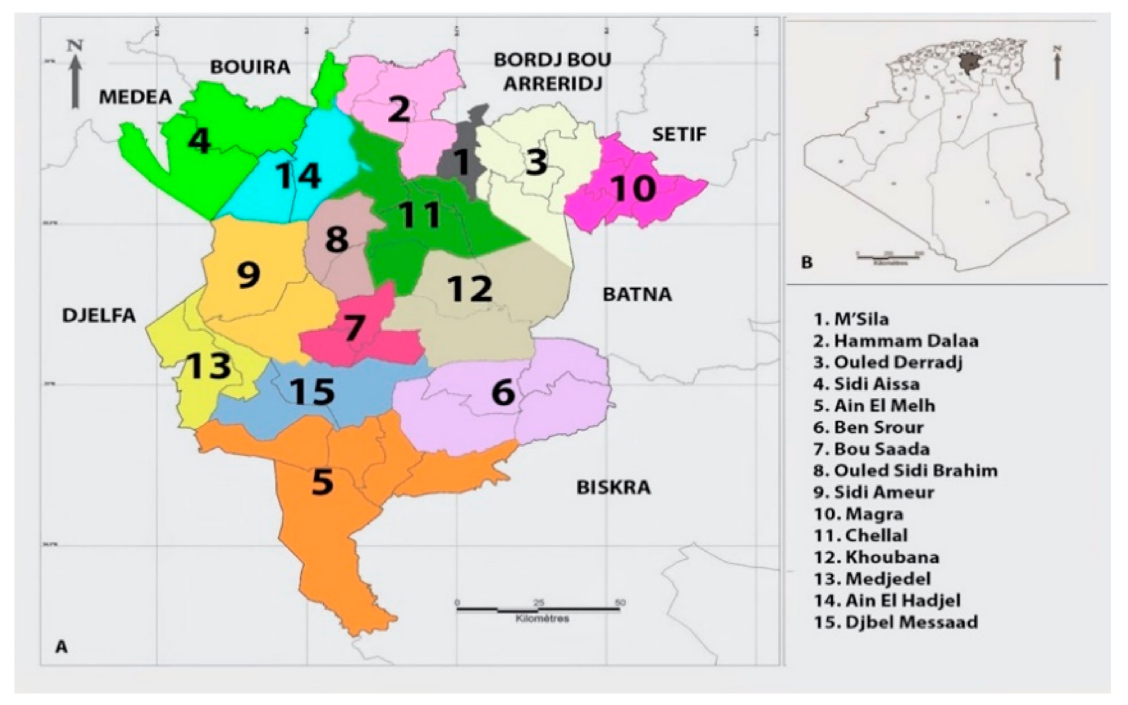

Figure 2. Administrative districts (Daïras) of the M'Sila province.

Table 1. Description of stations sampled during the entomological survey performed in 2003/2004 and 2018.

\begin{tabular}{|c|c|c|c|c|c|c|}
\hline \multirow{2}{*}{ Districts } & \multirow{2}{*}{ Station Name } & \multirow{2}{*}{ Geo Reference } & \multirow{2}{*}{$\begin{array}{l}\text { Elevation } \\
\text { (m) }\end{array}$} & \multirow{2}{*}{ Description } & \multicolumn{2}{|c|}{ Specimen } \\
\hline & & & & & $\mathbf{n}$ & $\%$ \\
\hline \multirow{2}{*}{ M'sila } & Naoura & $35^{\circ} 39^{\prime} \mathrm{N} / 04^{\circ} 31^{\prime} \mathrm{E}$ & 475 & $\begin{array}{l}\text { Rural area. Ovine and } \\
\text { bovine population. }\end{array}$ & 1264 & 11.81 \\
\hline & Boukhmissa & $35^{\circ} 43^{\prime} \mathrm{N} / 04^{\circ} 33^{\prime} \mathrm{E}$ & 475 & $\begin{array}{l}\text { Urban area, with a bovine } \\
\text { population. }\end{array}$ & 173 & 1.62 \\
\hline \multirow[t]{3}{*}{ Chellal } & Ouled Madhi & $35^{\circ} 34^{\prime} \mathrm{N} / 4^{\circ} 30^{\prime} \mathrm{E}$ & 415 & $\begin{array}{l}\text { Rural area. South of M'Sila, } \\
\text { outskirts of Hodna's chott. } \\
\text { Presence of rodent burrows. }\end{array}$ & 908 & 8.48 \\
\hline & $\begin{array}{l}\text { Khettouti Sed } \\
\text { El Djir }\end{array}$ & $35^{\circ} 37^{\prime} \mathrm{N} / 4^{\circ} 10^{\prime} \mathrm{E}$ & 460 & Rural area. & 82 & 0.77 \\
\hline & Ait Ikhlef & $35^{\circ} 36^{\prime} \mathrm{N}, 4^{\circ} 29^{\prime} \mathrm{E}$ & & Rural area. & 79 & 0.74 \\
\hline \multirow{3}{*}{ Magra } & Berrhoum & $35^{\circ} 39^{\prime} \mathrm{N} / 5^{\circ} 2^{\prime} \mathrm{E}$ & 596 & Rural area. & 33 & 0.31 \\
\hline & Ain El Khadra & $35^{\circ} 32^{\prime} \mathrm{N} / 4^{\circ} 58^{\prime} \mathrm{E}$ & 446 & Rural area. & 11 & 0.10 \\
\hline & Dehahna & ND & ND & Rural area. & 60 & 0.56 \\
\hline Hammam Dalaa & El Guetaf & ND & ND & ND & 64 & 0.60 \\
\hline OuledDerradj & Maadid & $35^{\circ} 55^{\prime} \mathrm{N} / 04^{\circ} 22^{\prime} \mathrm{E}$ & 1000 & Rural and semi-arid areas. & 301 & 2.83 \\
\hline Ain El Hadjel & Ain El Hadjel & $35^{\circ} 40^{\prime} \mathrm{N} / 03^{\circ} 52^{\prime} \mathrm{E}$ & 500 & Steppe with farming & 2773 & 25.90 \\
\hline Sidi Aissa & Sidi Aissa & $36^{\circ} 30^{\prime} \mathrm{N} / 04^{\circ} 17^{\prime} \mathrm{E}$ & 1003 & Rural area. & 50 & 0.47 \\
\hline Ain El Melh & Ain El Melh & $34^{\circ} 50^{\prime} \mathrm{N} / 04^{\circ} 9^{\prime} \mathrm{E}$ & 948 & Rural area. & 20 & 0.19 \\
\hline Bou Saâda & Boussaâda & $35^{\circ} 12^{\prime} \mathrm{N}-04^{\circ} 12^{\prime} \mathrm{E}$ & ND & $\begin{array}{l}\text { Palm grove and Oued. } \\
\text { Presence of goats, chickens, } \\
\text { and pigeons }\end{array}$ & 4888 & 45.66 \\
\hline
\end{tabular}

ND: not determined, n: number of samples collected, \%: percentage compared to the total number of catches done.

Rodents were trapped from 1996 to 2018 to determine the wild rodent population diversity. A prospective study on suspected CL and other suspected human and canine visceral leishmaniasis was carried out from October 2018 to February 2019.

\subsection{Entomological Sampling}

Sandflies were collected from March to October 2003/2004 during the active season of transmission in 13 stations from 9 districts (Figure 3). 


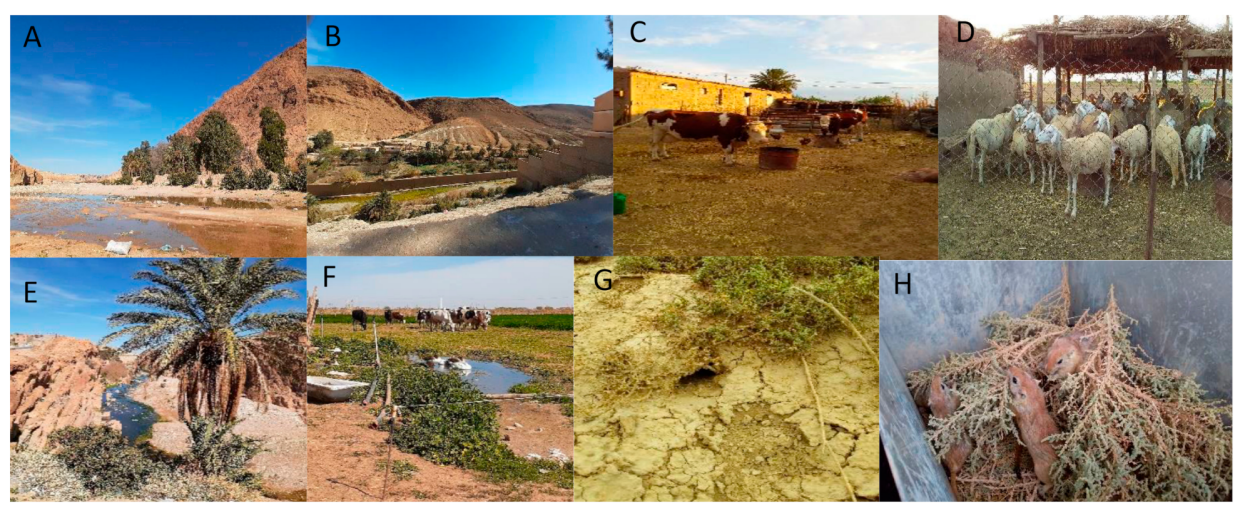

Figure 3. Pictures depicting the diversity of the ecological environment of the trapping station. ((A,B,E) (Bou Saâda), (C,D), (Ait Ikhlef, Chellal), (F) (Ain El Hadjel), (G,H) (Ouled Madhi, Chellal)).

In five stations (Nouara, Ouled Madhi, Maadid, Ain El Hadjel, Boussaâda), the trapping effort was carried out twice a month over the transmission season (March to October). The other trapping sites were sampled one time along east-west and northsouth transects. Sandflies were collected using adhesive paper $(20 \mathrm{~cm} \times 20 \mathrm{~cm}$ papers soaked in castor oil) and CDC light traps (John W., Hock Co., Gainesville, FL, USA) as described by Rioux et al. [21]. Specimens were collected and stored in glass vials containing $70 \%$ ethanol for morphological identification, using dichotomous keys of Abonnenc [22], Croset et al. [23], and Dedet et al. [24]. Seasonal fluctuation of the sandfly population was ascertained in the station of Ain El Hadjel (Table 1).

\subsection{Rodent Capture}

Trapping of rodents was performed during 1996, 2003, 2004, 2007, 2010, 2012, and 2018, based on indications of their presence (burrows, fragments of Chenopodiaceae plants, droppings, and traces of urine). Sherman traps were placed along a transect of the salt-lake (sebkha) and down the hills' piedmont (Table 2).

Rodents were anesthetized with carbon monoxide (CO); morphological identification was performed according to identification keys described by Bernard [25]. Auricle, muzzle, legs, and tail exposed to insect bites were carefully examined. A biopsy of lesions was taken and smeared on a glass slide and stained with Giemsa. A portion of the sample was inoculated into an NNN medium supplemented with few Penicillin antibiotic drops $(1 \mathrm{U} / \mathrm{mL})$ solution under sterile conditions [26,27].

The spleen was collected and homogenized in microtubes containing PBS with singleuse pellet pestles (Polylabo, France). Aliquots of the suspension were stored at $-20^{\circ} \mathrm{C}$ until DNA extraction. According to the manufacturer protocol, the total DNA was purified using the QIAamp DNA mini kit (QIAGEN). Parasite DNA was detected by PCR amplification of the ribosomal internal transcribed spacer 1 (ITS1), using LITSR and L5.8S primers [28].

\subsection{Patient: Skin Wound Sampling Collection}

Ninety-six patients with evocative CL lesions were recruited during a routine diagnosis of the disease. Sixty patients were from Boussaâda and 36 from M'Sila city. Skin lesions were scarified using a curved sterile scalpel blade (Swann-Morton-Sinner, France), as described in the WHO guidelines for diagnosing human CL [29]. Exudates from dermal lesions were spotted onto microscope slides, inoculated into a culture medium, and processed for DNA extraction. Blood samples from two children with symptoms of visceral leishmaniasis and 18 members of their family and a dog living in the same house were sampled in an EDTA coated flask (Vacutest Kima, Arzergrand, Italy). 
Table 2. Description of stations sampled during the survey of rodents performed from 1996 to 2018.

\begin{tabular}{|c|c|c|c|c|c|c|c|}
\hline Locality & Family & Genus/Species & Year & N Tot & N Inv & N Inf & N Isol \\
\hline \multirow{6}{*}{ Chellal, Sidi Aissa, other } & \multirow{7}{*}{ Gerbillidae } & \multirow{7}{*}{ Psammomys obesus } & 1996 & ND & ND & ND & 3 \\
\hline & & & 2003 & ND & 10 & 7 & 4 \\
\hline & & & 2004 & 60 & 30 & 5 & 4 \\
\hline & & & 2007 & ND & ND & ND & 6 \\
\hline & & & 2010 & 223 & 144 & 43 & - \\
\hline & & & 2018 & ND & 12 & - & - \\
\hline \multirow{7}{*}{$\begin{array}{c}\text { M'Sila, Sidi Aissa, Magra, } \\
\text { Ain-El-Hadjel }\end{array}$} & & & 1996 & ND & ND & ND & 1 \\
\hline & \multirow{6}{*}{ Gerbillidae } & \multirow{6}{*}{ Meriones shawi } & 2000 & ND & ND & ND & 1 \\
\hline & & & 2004 & ND & 10 & 3 & - \\
\hline & & & 2008 & 49 & 20 & 6 & - \\
\hline & & & 2009 & ND & ND & ND & 2 \\
\hline & & & 2012 & 12 & 6 & 1 & - \\
\hline & & & 2018 & ND & 1 & - & - \\
\hline M'Silasila & Gerbillidae & Meriones lybicus & ND & 13 & 6 & - & - \\
\hline Boussaâda, M'Sila, & \multirow{2}{*}{ Gerbillidae } & \multirow{2}{*}{ Gerbillus sp. } & ND & 46 & ND & - & - \\
\hline Ain-El-Hadjel, Khoubana & & & 2018 & ND & 3 & - & - \\
\hline Boussaâda & \multirow[t]{2}{*}{ Gerbillidae } & \multirow[t]{2}{*}{ Ctenodactylus gundi } & ND & 12 & 12 & - & - \\
\hline Ain-El-Melh & & & 2018 & ND & 2 & - & - \\
\hline M'Sila, Hamama, Delaa & Dipodidae & Jaculus jaculus & ND & 12 & 6 & - & - \\
\hline $\begin{array}{l}\text { Ain-El-Melh, Khettouti, } \\
\text { Sed-El-Djir }\end{array}$ & Dipodidae & Jaculus orientalis & ND & 11 & 4 & - & - \\
\hline $\begin{array}{l}\text { Ain-El-Mehl, Boussaâda, } \\
\text { Hamama, Dalaa, Khettouti, } \\
\text { Sed-El-Djir }\end{array}$ & Muridae & Rattus ratus & ND & 5 & 5 & - & - \\
\hline \multirow[t]{2}{*}{ Hamama, Dalaa } & Macroscelidae & Elephantus rozeti & ND & 2 & 2 & - & - \\
\hline & & & Total & 445 & 273 & 65 & 21 \\
\hline
\end{tabular}

ND: not determined, $\mathrm{N}$ Tot: total number of specimens collected, $\mathrm{N}$ Inv: number of sampled identified and processed for parasite identification, N Inf: number of specimens infected according to parasitological and molecular investigations, $\mathrm{N}$ Isol: number of isolates.

\subsection{Parasitological Diagnosis}

Direct microscopic examination of smears was performed for all suspected CL patients. Thus, smears were stained with Giemsa and examined at $100 \times$ magnification. Exudates were seeded in an NNN medium supplemented with few drops of antibiotic (Penicillin $1 \mathrm{U} / \mathrm{mL}$ ) in sterile saline solution $[26,27]$ and then sub-cultured every week for four weeks. The buffy coat extracted from the blood of VL cases, their family members, and the dog samples were inoculated into both NNN and rabbit's coagulated serum medium [30].

\subsection{Molecular Diagnostic and Typing}

DNA was extracted from the exudates of lesions of 96 patients suspected of CL as well as from the previous 21 blood samples using the QiAamp DNA Blood Mini Kit (Qiagen ${ }^{\circledR}$, Hilden, Germany), according to the manufacturer's instructions. The DNA was eluted in $50 \mu \mathrm{L}$ of Tris EDTA (TE) buffer and stored at $-20{ }^{\circ} \mathrm{C}$ until used. Promastigotes of the following three Leishmania reference strains were used as a control: L. infantum (MHOM/FR/78/LEM75), L. tropica (MHOM/DZ/05/LIPA07/05), and L. major (MHOM/DZ/82/LIPA80).

Typing was performed by PCR-ITS1 (Polymerase Chain Reaction-Internal Transcribed Spacer 1 genes) and RFLP (Restriction Fragment Length Polymorphism). The amplification was carried out in a volume of $50 \mu \mathrm{L}$ containing $5 \mu \mathrm{L}$ of DNA, $4.0 \mathrm{mM}$ of $\mathrm{MgCl}_{2}, 200 \mu \mathrm{M}$ dNTP's, $500 \mathrm{nM}$ of each primer (LITSR: 5'-CTGGATCATTTTCCGATG-3', and L5.8S: 5'TGATACCACTTATCGCACTTA- $\left.3^{\prime}\right), 2 \mathrm{U}$ of Taq polymerase. The amplification conditions were $94{ }^{\circ} \mathrm{C}$ for $4 \mathrm{~min}$, followed by 36 cycles of $95^{\circ} \mathrm{C}$ for $40 \mathrm{~s}, 53{ }^{\circ} \mathrm{C}$ for $30 \mathrm{~s}, 72{ }^{\circ} \mathrm{C}$ for $60 \mathrm{~s}$, and $72{ }^{\circ} \mathrm{C}$ for $6 \mathrm{~min}$ [28]. DNAs of reference strains and water were used as positive and negative controls. The amplification product was analyzed on a $2 \%$ agarose gel and visualized under ultraviolet light. The presence of the 300 and 350 base pair bands 
compatible with those of the reference strains was analyzed. Then, positive samples were incubated at $37^{\circ} \mathrm{C}$ for $24 \mathrm{~h}$ with the endonuclease enzyme HaeIII (Hybaid GmbH, Heidelberg, Germany) to identify the parasite at the species level. After electrophoresis on $2 \%$ agarose gel and visualization under ultraviolet light, the lengths of the bands obtained were compared with those of the reference strains [28].

Real-time qPCR amplification of the kDNA was performed were carried out in a volume of $25 \mu \mathrm{L}$ containing $1 \mu \mathrm{L}$ of DNA in $24 \mu \mathrm{L}$ of a master mix (Taq Man Universal Master mix II with UNG (Applied)) having $100 \mathrm{nM}$ of each primer (5'-CTTTTCTGGTCCTCCGGGT AGG-3') and (5'-CCACCCGGCCCTATTTTACACCAA-3'), $50 \mathrm{nM}$ the probe (FAM 5'TTTTCGCAGAACGCCCCTACCCGC-3'). The DNA was amplified with a Taq Man Applied Biosystems 1 apparatus (Applied Biosystems, Foster City, CA, USA). The amplification conditions were $95^{\circ} \mathrm{C}$ for $2 \mathrm{~min}$, followed by 40 cycles of $95^{\circ} \mathrm{C}$ for $15 \mathrm{~s}, 60^{\circ} \mathrm{C}$ for $1 \mathrm{~min}$, and $60^{\circ} \mathrm{C}$ for $1 \mathrm{~min}$. Reactions were validated with positive and negative control samples. The DNA of the samples was quantified against a serial dilution of Leishmania DNA extracted from a known number of parasites ( 0.5 to 0.005 parasites per reaction tube). Real-Time PCR was considered positive when the test sample's cycle threshold was below that of the last point of the range, in a valid reaction [31].

\subsection{Sequencing and Phylogeny of Chosen Isolates}

ITS1 amplicons were purified using ExoSAP (ThermoScientific, EU). Leishmania species were identified by DNA sequencing using an ABI Prism1 Big Dye ${ }^{\mathrm{TM}}$ Terminator, $\mathrm{Cy}-$ cle Sequencing Ready Reaction Kit, and AB1 3130 sequencing system (ABI, PE Applied Biosystems), with the same primers used for PCR. DNA sequences from both strands were aligned and edited using the Staden software package [32]. The MEGA version 7 software [33] was used to conduct multiple sequence alignments (ClustalW option) and construct a phylogenic tree. Homology searches were performed using BLAST (Basic Local Alignment Search Tool) using the NCBI (National Center for Biotechnology Information) server [34]. The generated sequences were aligned using SeaView4 [35] to study the targeted genes' genetic variability. Phylogenetic analysis was carried out using maximum likelihood analysis with the online phylogeny website (www.phylogeny.fr, accessed on 15 October 2020) [20,36]. Alignments were done with the ITS1 sequences of L. donovani from Senegal (MN244151.1) and China (MH202978.1), L. infantum from Italy (KU680955.1), Morocco (KX664454.1) and France (AJ634339.1); L. tropica from Morocco (KM454152.1), Libya (KP691595), Tunisia (JN104588.1); L. aethiopica from Ethiopia (FN677356.1); L. major from Iraq (KY882275.1), Uzbekistan (FN677357.1), Tunisia (FN677342.1); L. panamensis (HG512959.1); L. braziliensis (HG512942.1); L. martiniquensis (MG731229.1). C. fasciculata was used as an outgroup (JX683017.1).

\subsection{Multilocus Enzymatic Electrophoresis (MLEE) Typing}

Eighty-seven isolates were analyzed with MLEE ( 66 from humans and 21 from rodents, including 23 isolates collected during the survey performed in 2018/2019. The remaining 43 human isolates were taken from the cryobank of the Institut Pasteur of Algeria. The isoenzyme characterization of isolates was carried out using 15 enzyme systems, according to the protocol previously described by Rioux et al. [37].

\subsection{Data Management and Statistical Analysis}

Data management and analysis were performed using Excel 365 (Microsoft office, USA); Graph-prism (8.02, GraphPad Software Inc., San Diego, CA, USA); XL STAT (v2020, Addinosoft) and Stata 11 (v16.1, StataCorp, TX, USA). Maps that relate the spatial distribution of CL cases and the cumulative incidence within the 48 provinces and the cumulative number of patients in the 15 districts of M'Sila were constructed using Photoshop (v2015, Adobe). A one-factor ANOVA analysis used to test CL per province's incidences per year was performed using the Graph-prism (v8.02, GraphPad Software Inc). and Stata 
11 software. Dunnett's post-test was used when the ANOVA $p$-value was less than 0.05 . A principal component analysis (PCA) was performed using XL STAT.

\subsection{Ethical Considerations}

The study protocol, informed consent forms, and sampling/experimental procedure were reviewed and approved by the Ethical Committee of Institut Pasteur of Algeria (the study began after obtaining the informed consent from patients under Helsinki's declaration (1964)). All animal experiments carried out in vivo comply with the guidelines of the Veterinary Inspection department of Algiers (veterinary health declaration established by the chief veterinary inspector, $N^{\circ} 2505$ / IVWA / 2019 in April 2020 and approved by the Research Ethics Committee of the Institut Pasteur of Algeria, and also approved by the Algerian Association for the Sciences of Animal Experimentation (AAAES).

\section{Results}

\subsection{Dynamics of Cutaneous Leishmaniasis in the Province of M'Sila Compared to the National} Epidemiological Status of the Disease

From 1982 to 2017 (34-year period), more than a quarter of a million cases $(252,659)$ of $\mathrm{CL}$ were registered in the country (Figure 4A). During this period, five provinces (Bechar, El Oued, Batna, Biskra, and M'Sila) recorded more than $70 \%$ of the total cases (Figure $4 \mathrm{~B}$ ).

Since 1982, the dynamics of CL reveals an endemic-epidemicity status of the disease, with several peaks observed, the most critical being in 2005 with more than 25,511 cases recorded in the country (Figure 5B). Statistical analysis disclosed a highly significant difference (ANOVA 1-way test, $p<0.0001$ ) in the annual distribution of recorded cases over the 34 years. As compared to 2005, the incidence appears to be significantly different to other years, except for 2004, 2006, 2010, and 2011. The disease's endemic-epidemicity is also observed in M'Sila, a province with approximately 90,000 cumulative cases since 1982 and seven epidemic peaks in 1982, 1987, 1991 and 1997, 2005, 2010, and 2017 (Figure 5A,B).

\section{(A)}
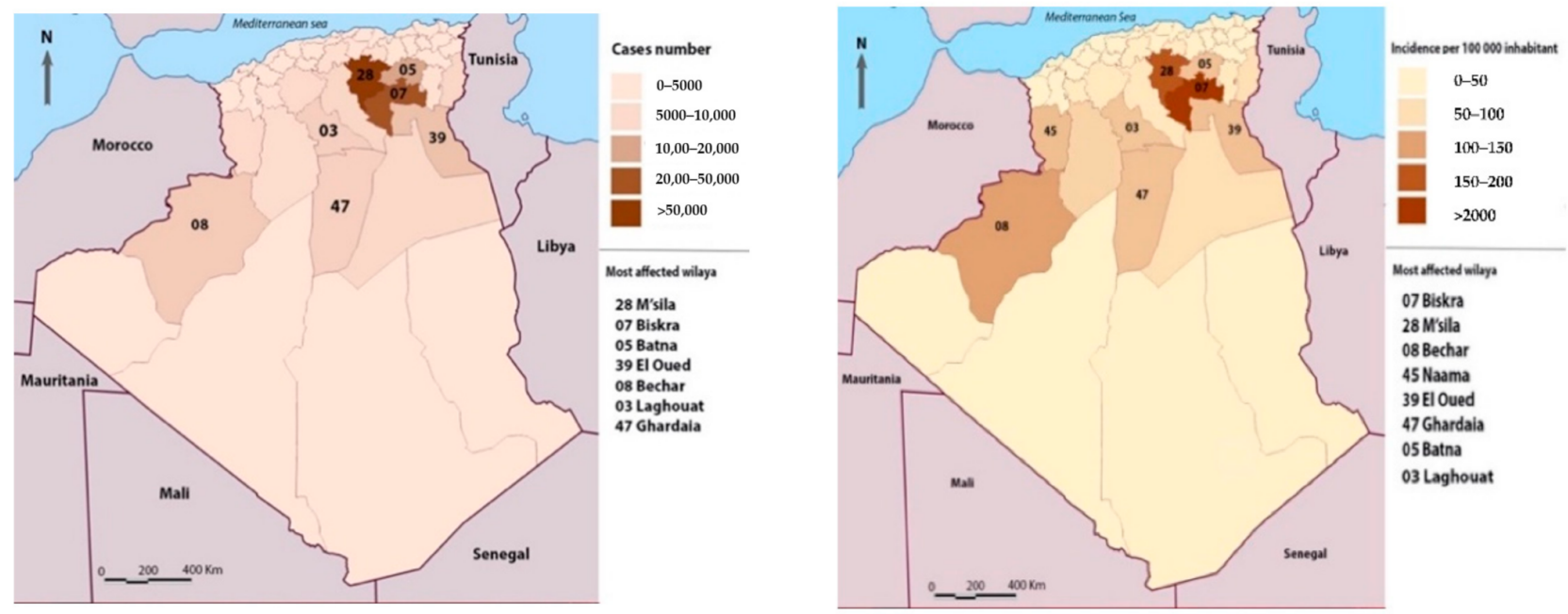

Figure 4. Cont. 
(B)

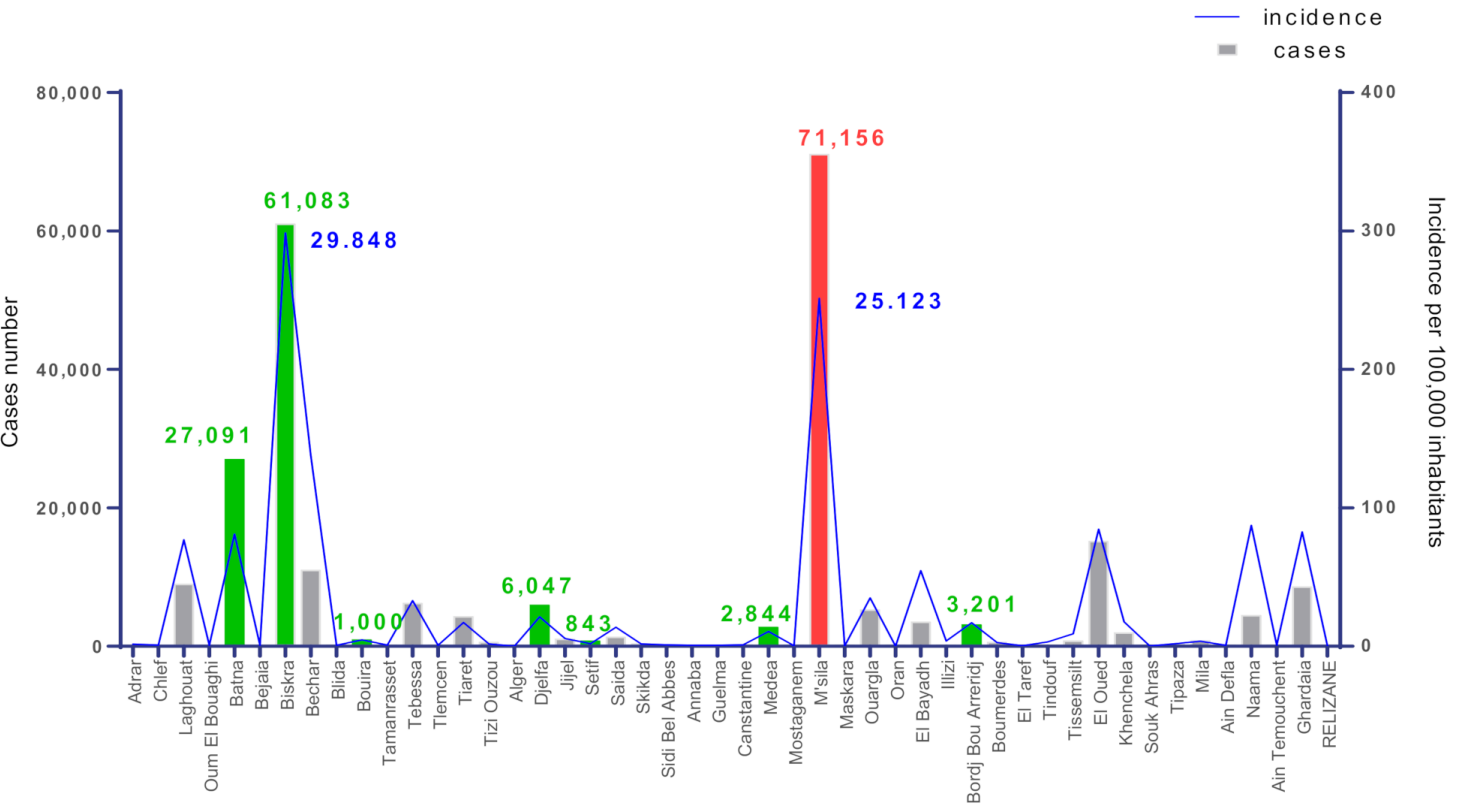

Figure 4. Total case number and incidence recorded during the 1982 to 2017 period. (A) The geographic location of registered cases (right panel) and incidence (left panel) during the 1982 to 2017 period. (B) Total cumulative cases and incidences per province during the period from 1982 to 2017. Provinces bordering M'Sila (red) are denoted by green color.

The district of M'Sila is significantly more affected in terms of the number of cumulative cases than the rest of the districts (1-way ANOVA test, $p<0.0001)$. A higher CL case incidence was reported in M'Sila than in the former foci of Biskra (Dunnett's post, $p<0.05$ ) (Figure 6A,B).

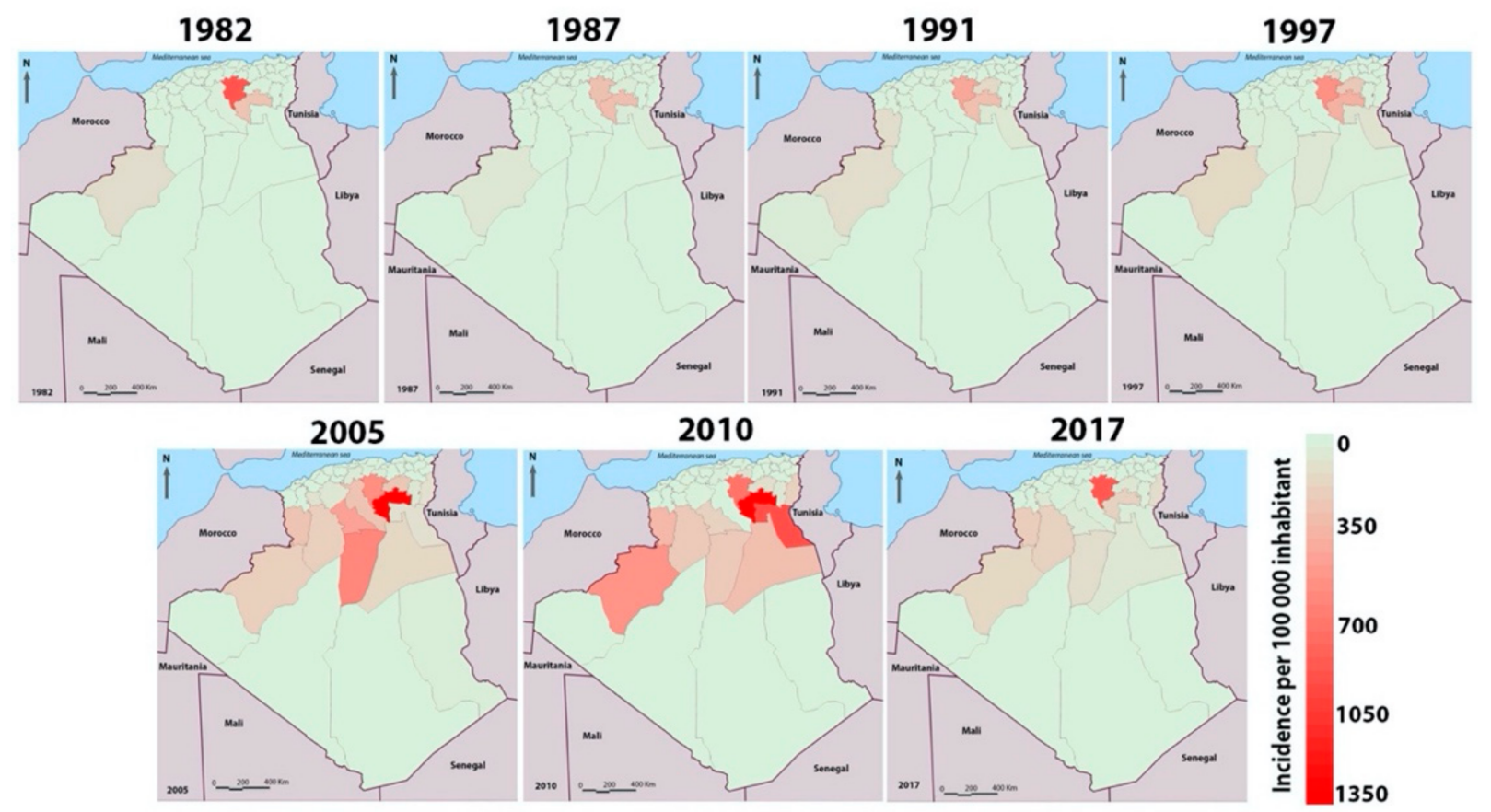

(A)

Figure 5. Cont. 
$\rightarrow$ CASES

$\rightarrow-$ INC CUMUL

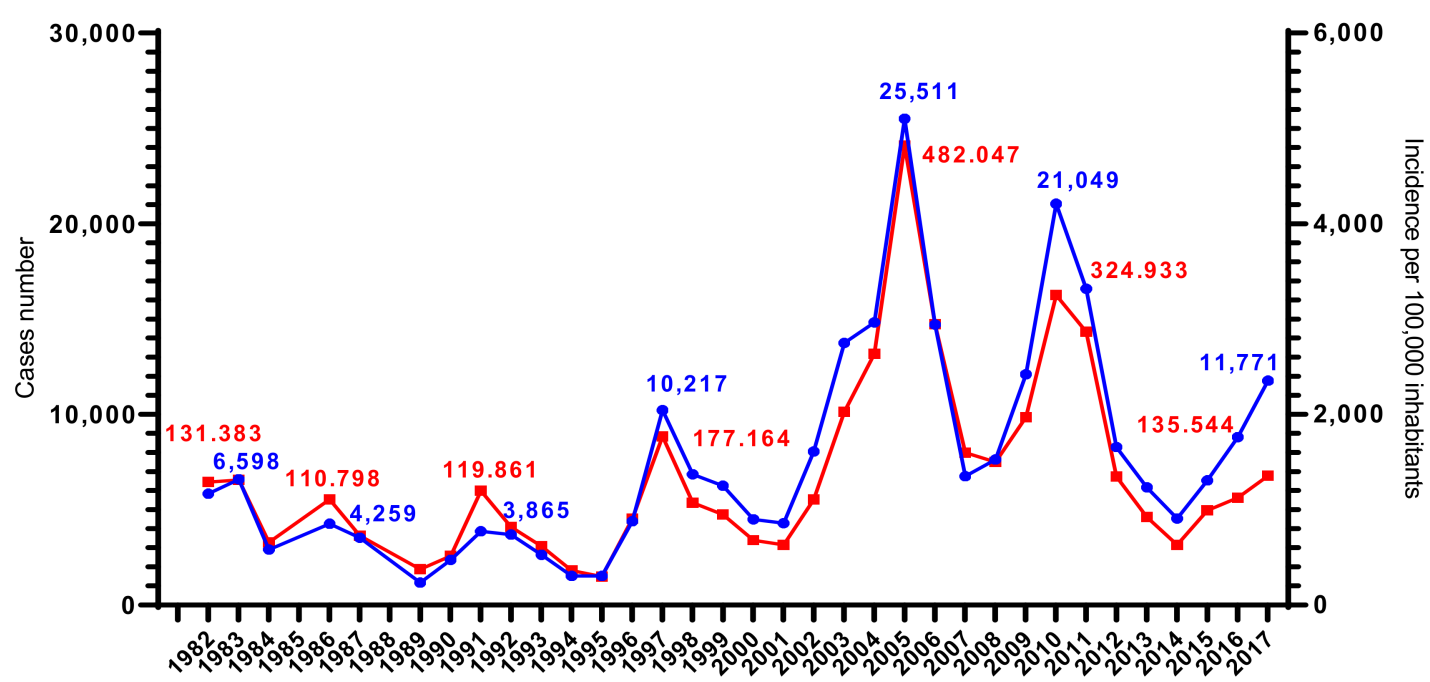

Years

(B)

Figure 5. Total case number and incidence of cutaneous leishmaniasis from 1982 to 2017 in Algeria. (A) Spatial distribution of cutaneous leishmaniasis cases during the seven epidemic outbreaks recorded in Algeria. (B) Cutaneous leishmaniasis cases cumulative incidence (INC CUMUL) in Algeria over the period from 1982 to 2017.
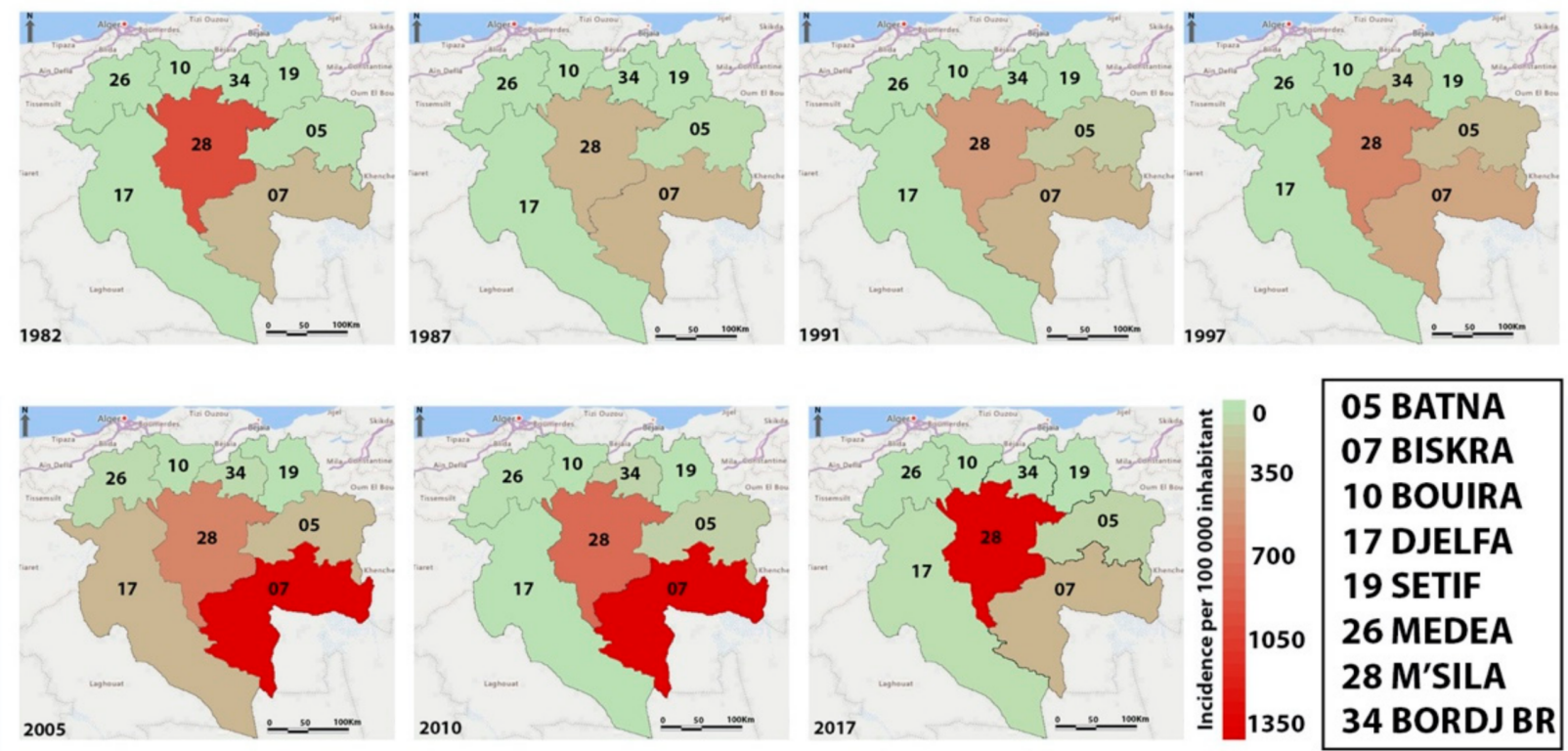

(A)

Figure 6. Cont. 


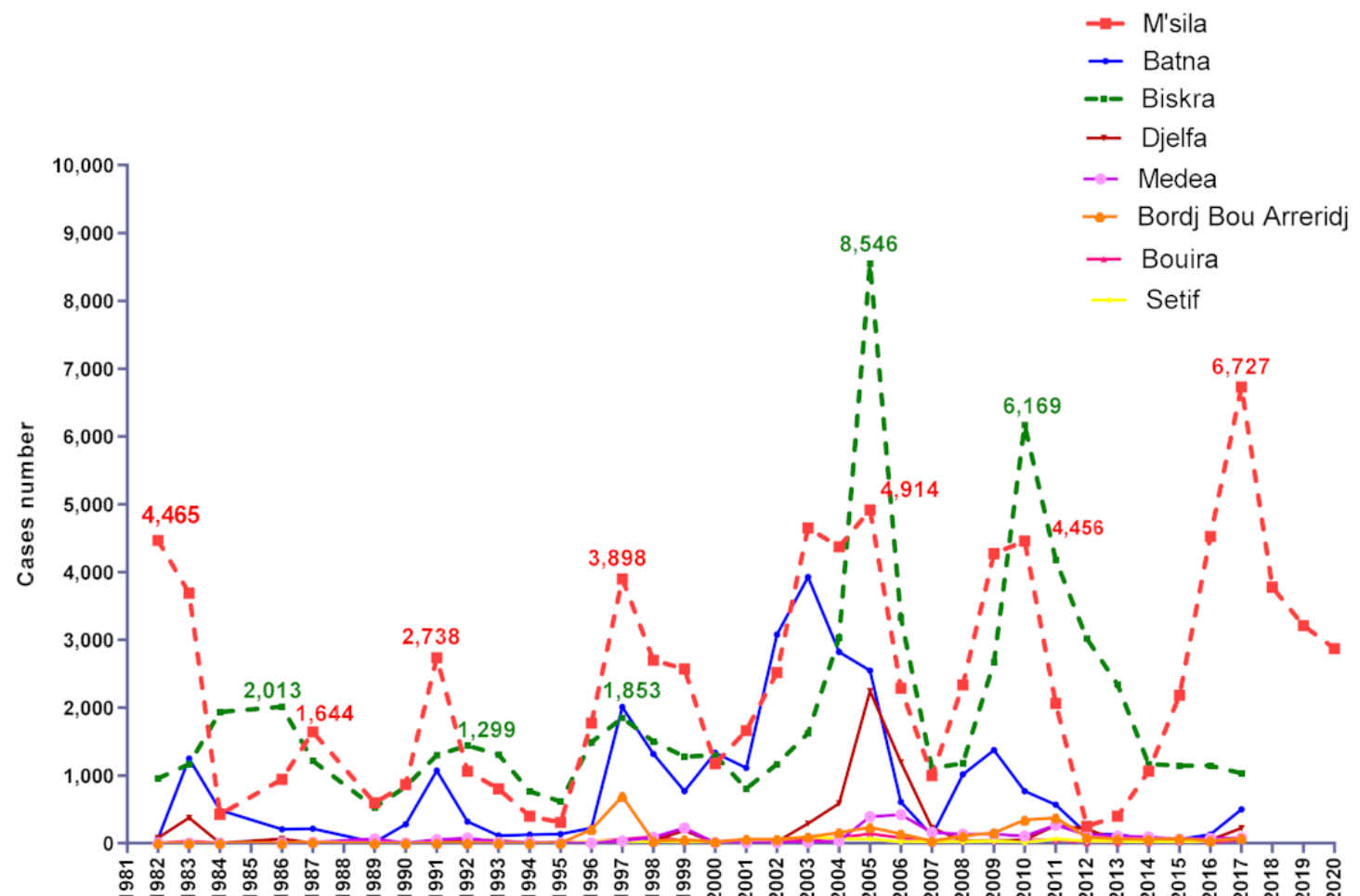

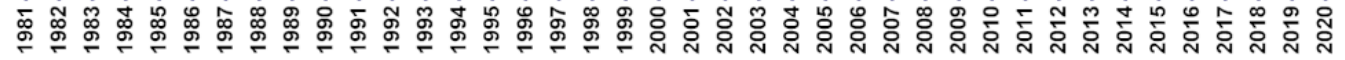

Years

(B)

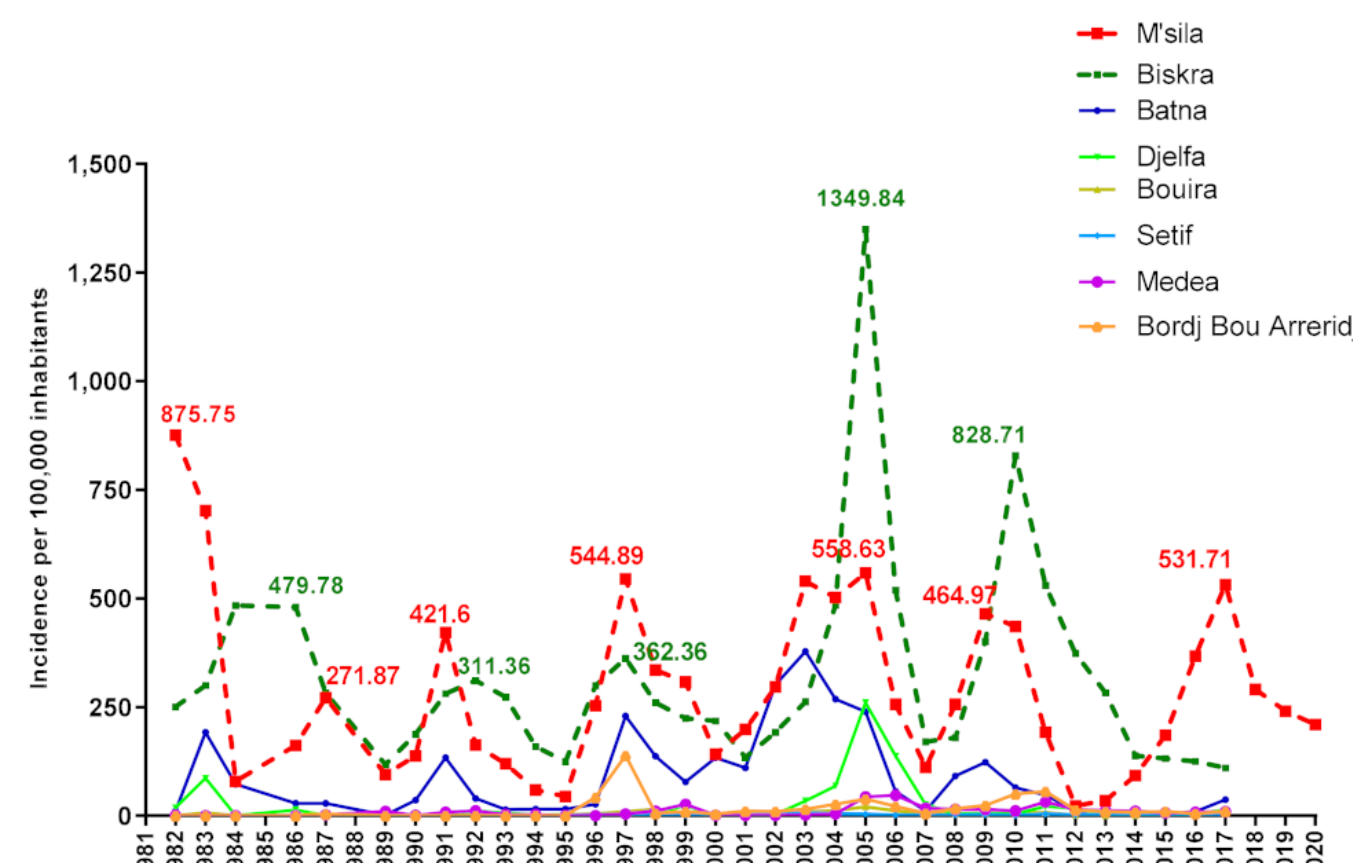

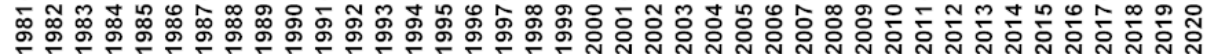

Years

(C)

Figure 6. Representation of cutaneous leishmaniasis incidence in M'Sila and the seven bordering provinces. (A) Spatial representation of CL incidence during the seven major epidemic outbreaks. (B) Cases number and (C) incidence of cutaneous leishmaniasis during the period from 1982 to 2020. 
The analysis of CL cases registered in the province of M'Sila from 2010 to 2020 depicts that all districts are affected. Four out of the 15 districts reported more than 3000 cumulative cases during the last decade, M'Sila (4932), Ouled Derradj (3381), Boussaâda (3361), and Magra (3311), respectively, followed by the district of Chellal, Hammam Dalaa, Bensrour, Khoubana, Ain El Melh, and Sidi Aissa which recorded less than 3000 cases (Figure 7).

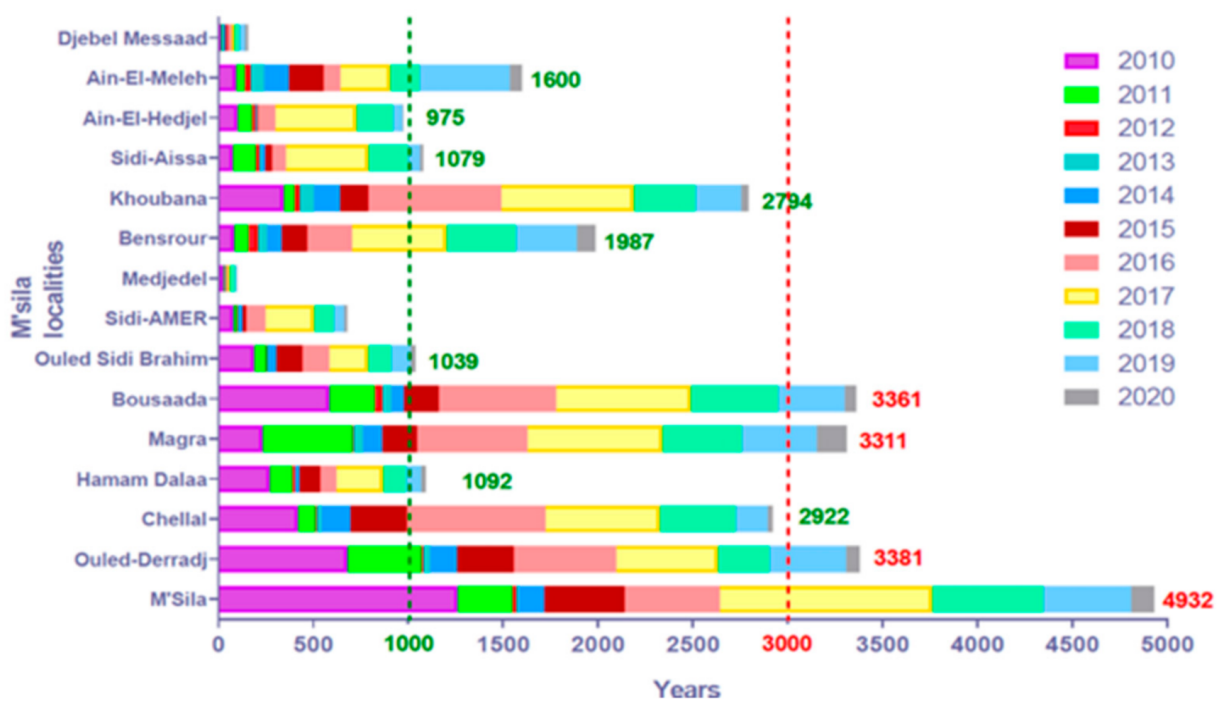

Figure 7. Temporal dynamic of cutaneous leishmaniases cases recorded in the 15 districts of the province of M'Sila over the last decade (2010-2020).

\subsection{Cutaneous Leishmaniasis in the M'Sila Province}

\subsubsection{Lesion Characteristics, Patient Stratification, and Environmental Features}

Of the 96 suspected CL patients, 74\% [65.4-82.6] were positive for at least one of the used diagnostic methods (i.e., direct microscopic examination, in vitro culture, PCR-ITS1, qPCR). Fifty patients (71.6\% [59.7-82.1]) presented ulcerative lesions and 13 patients a nodular form (19.4\% [10.4-29.9]). Forty-three patients (61.4\% [50.0-72.8]) had more than one lesion, among whom 11 (15.7\% [7.1-24.3]) exhibited a minimum of 4 lesions. Arms and legs are the most affected parts of the body (50 patients, 70.4\% [59.6-81.2]). A single facial lesion was observed in 21 patients (29.6\% [18.8-40.4]). Patient age: CL affected all age categories from 9 months to 73 years, with 7.5 years as a median age. Fifty-four patients $(76.1 \%)$ were less than 15 years old, with the most affected less than 5 years old (31 cases, 43.7\% [32.4-54.9]), followed by those between 6 and 10 years of age (15 cases, $21.1 \%$ [11.3-31]). Patients over 15 years of age represented $23.9 \%$ of the total cases. Females are slightly more affected than males (40 females: (56.3\% [45.1-67.6], 31 males: (43.7\% [32.4-54.9]), with a sex ratio of 1.3. The sex ratio was equal to 1 in children under 5 years of age. The highest number of cases was recorded in the Daïras of Boussaâda (18 cases, 25.4\% [15.5-36.6]) and M'Sila (14 cases, 19.7\% [11.3-29.6]). Most patients live in rural areas, 66.2\% [54.4-76.5]. The presence of domestic animals or rodents in or near a dwelling was reported by 41 patients (59.2\% [47.9-70.4]). Thirty-seven patients (52.1\% [43.9-68.2]) signaled CL cases among their family $(85.3 \%)$ or in their neighbors $(20.6 \%)$.

\subsubsection{Leishmania Detection and Identification in Patients and Reservoirs}

The results of the diagnostic methods performed on skin samples of humans suspected of CL are summarized in Table 3. 
Table 3. Diagnostics of the 96 Leishmania isolates, using parasitological (Giemsa staining and in vitro culture) and molecular methods (PCR-RFLP and qPCR).

\begin{tabular}{ccccccc}
\hline \multicolumn{2}{c}{ Number of Samples } & \multicolumn{2}{c}{$\%$} & \multicolumn{2}{c}{ Sensitivity } \\
\hline Test & \multicolumn{1}{c}{$\begin{array}{c}\text { Positive } \\
\text { Case }\end{array}$} & $\begin{array}{c}\text { Negative } \\
\text { Case }\end{array}$ & $\begin{array}{c}\text { Positive } \\
\text { Case }\end{array}$ & $\begin{array}{c}\text { Negative } \\
\text { Case }\end{array}$ & & IC \\
\hline Smears & 44 & 52 & 45.83 & 54.16 & 62 & {$[50.7-73.3]$} \\
\hline Culture & 51 & 44 & 53.68 & 46.31 & 72.9 & {$[62.4-83.3]$} \\
\hline ITS1-PCR & 54 & 40 & 57.44 & 42.55 & 78.3 & {$[66.5-88.0]$} \\
\hline RT-PCR & 69 & 25 & 73.40 & 26.59 & 100 & {$[94.8-100]$} \\
\hline Total & 71 & 25 & 73.95 & 26.04 & & \\
\hline
\end{tabular}

Among the suspected CL patients, $45.83 \%$ were recorded positive based on direct examination and $53.68 \%$ based on culture. A higher positivity rate was recorded for molecular methods, reaching $73.40 \%$ using qPCR. In total, 71 patients were diagnosed as CL positive (Table 3). Molecular identification (PCR-RFLP) disclosed that all $42 \mathrm{CL}$ samples and 21 gerbil samples tested were positive for L. major. Samples collected from humans with visceral symptoms (two cases) and from a dog (one case) belong to L. infantum (see Figure 8). Isolates characterized by MLEE ( 66 from humans and 21 from rodents) were identified as L. major zymodeme MON-25. A minor variation in 3 enzymatic complexes for G6PD, PGD, and ME is recorded in 10 isolates, suggesting the possible existence of L. major variants in this region. No discrepancy was observed between PCR-RFLP and MLEE results. A fragment amplified from the ITS1 gene was sequenced for seven isolates $(1 \mathrm{VL}, 1$ canine leishmaniasis, and $5 \mathrm{CL}$ ). Reference strains used were L. infantum MHOM/FR/78/LEM75, L. killicki (syn L. tropica) MHOM/TN/80/LEM163, and L. major MHOM/MA/81/LEM265 (7). L. infantum was identified in visceral leishmaniasis and canine leishmaniasis cases, whereas L. major was identified in CL cases. The identification of L. major in lesions of CL and the presence of L. infantum in dog and human suspected cases of VL were confirmed by the phylogenetic analysis of the ITS1 sequences (Figure 8B).
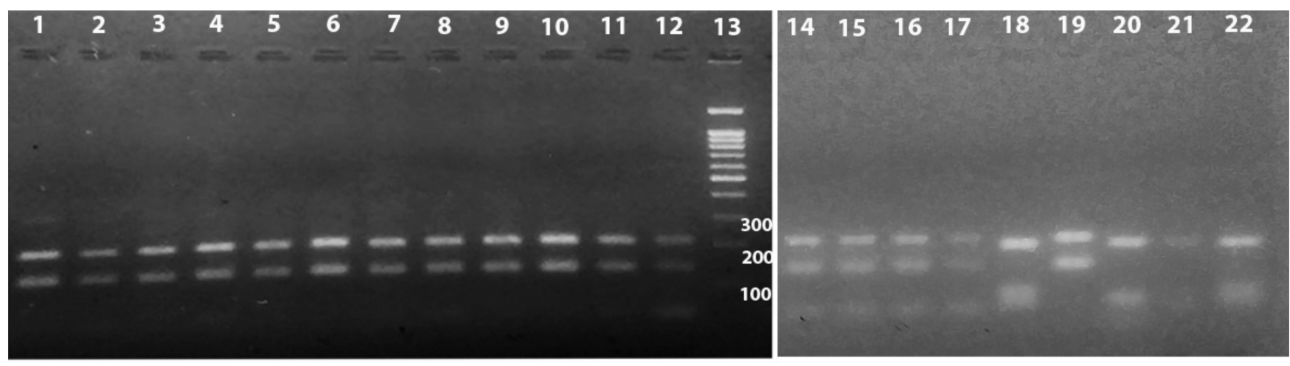

(A)

Figure 8. Cont. 


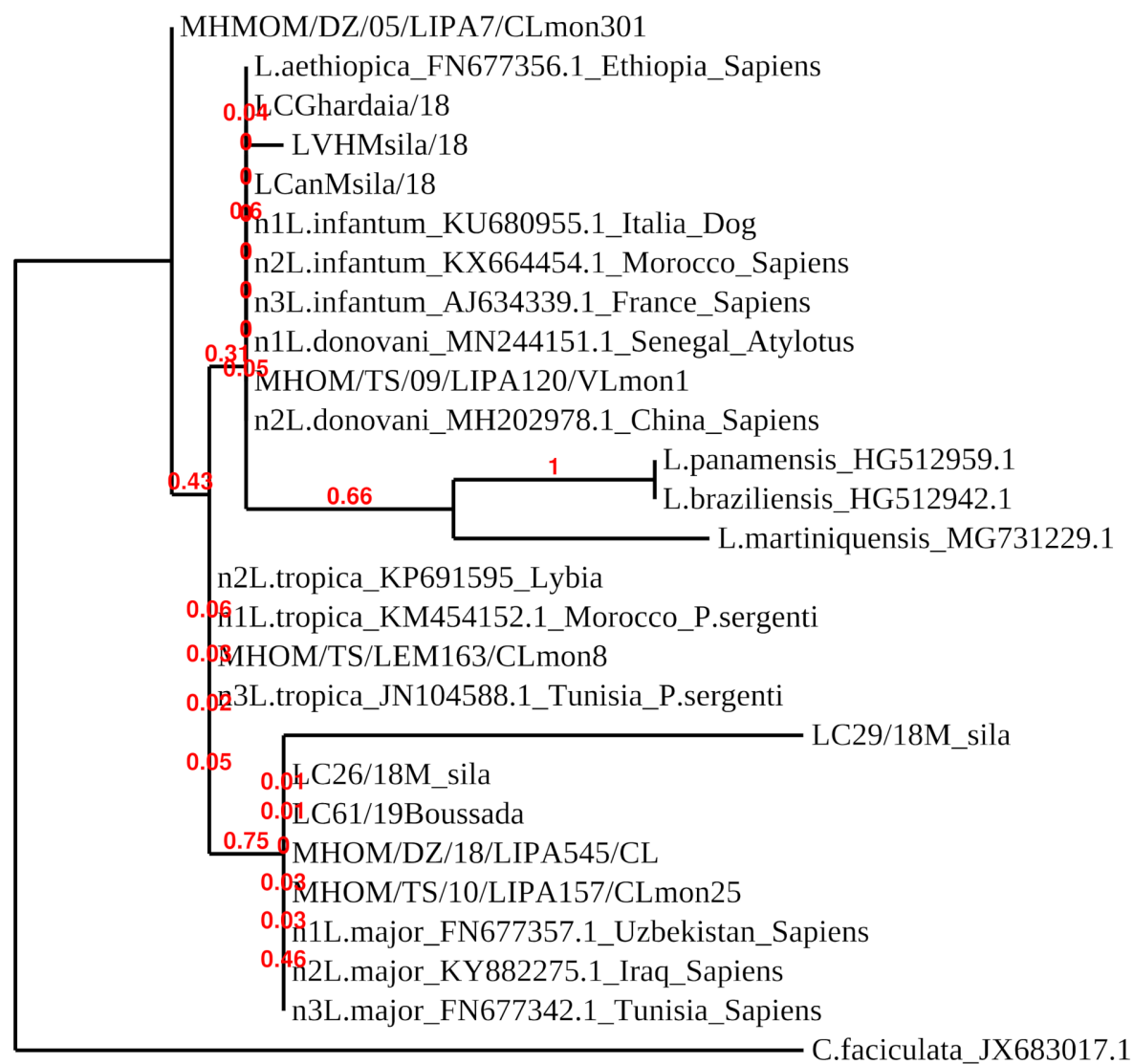

0.2

(B)

Figure 8. Identification of Leishmania isolates using molecular methodologies. (A) PCRRFLP of ITS1 as revealed after agarose gel electrophoresis. Lane 1, reference strain LIPA80 (L. major Mon-25); lane 2 to 9, isolates from Human Cutaneous Leishmaniasis; lane 10 to 11, isolates from P. obesus; lane 12, isolate from M. shawi; lane 13, MW (molecular weight marker); lane 14, reference strain LIPA80 (L. major); lane 15, a suspected variant of L. major strain (LIPA545/17); lane 16, LC61 (Leishmania isolate from Boussaâda); lane 17, LC80 (Leishmania isolate from Boussaâda); lane 18, reference strain LEM75 (L. infantum Mon-1); lane 19, LC61 (see above); lane 20, references strain LIPA07/05 (L. tropica Mon-301); lane 21, isolates from canine leishmaniasis (L. infantum); lane 22, isolates from human visceral leishmaniasis cases (L. infantum). (B) Phylogenetic reconstruction from ITS1 sequences of Leishmania isolates and references strains. An amplified fragment of the ITS1 gene was sequenced from 7 isolates (1 VL, 1 CanL, and $5 \mathrm{CL}$ ). Reference strains are L. infantum MHOM/FR/78/LEM75, L. killicki (syn L. tropica) MHOM/TN/80/LEM163, and L. major MHOM/MA/81/LEM265 (7).

\subsection{Entomological Survey in the Province of $M^{\prime}$ 'Sila}

3.3.1. Diversity and Dynamic of Sandfly Populations

A total of 10,706 specimens were caught, $99 \%$ of which were collected during the $2003 / 2004$ season and only 79 in 2018. Morphological identification revealed 16 species belonging to the genus Phlebotomus (89.53\%) and Sergentomyia $(10.47 \%)$. Details are given in Tables 4 and 5. Six new species have been identified for the first time in the province of M'Sila: P. perfiliewi, P. langeroni, P. chabaudi, S. clydei, S. schwetzi, and S. lewisi. 
Table 4. Identification of sandfly species belonging to the Phlebotomus genus collected during the survey.

\begin{tabular}{|c|c|c|c|c|c|c|c|c|c|c|}
\hline District & Station & P. papatasi & P. perniciosus & P. alexandri & $P$. sergent $i$ & P. chabaudi & P. longicuspis & P. perfiliewi & P. langeroni & Total \\
\hline \multirow{3}{*}{ M'Sila } & Nouara & 349 & 125 & 2 & 1 & 0 & 655 & 2 & 0 & 1134 \\
\hline & Boukhmissa & 73 & 30 & 0 & 1 & 0 & 9 & 0 & 0 & 113 \\
\hline & Ouled Madhi & 178 & 1 & 2 & 0 & 0 & 1 & 0 & 0 & 182 \\
\hline \multirow[t]{2}{*}{ Chellal } & Khettouti Sed & 52 & 1 & 0 & 1 & 0 & 0 & 0 & 0 & 54 \\
\hline & Ait Ikhlef & 60 & 5 & 0 & 0 & 2 & 3 & 0 & 0 & 70 \\
\hline \multirow{3}{*}{ Magra } & Berhoum & 23 & 6 & 0 & 0 & 0 & 1 & 0 & 0 & 30 \\
\hline & Ain El Khadra & 6 & 0 & 0 & 0 & 0 & 0 & 0 & 0 & 6 \\
\hline & Dehahna & 27 & 14 & 0 & 0 & 0 & 6 & 0 & 0 & 47 \\
\hline $\begin{array}{c}\text { Hammam } \\
\text { Dalaa }\end{array}$ & El Guetaf & 28 & 3 & 2 & 0 & 0 & 12 & 1 & 0 & 46 \\
\hline Ouled & Maadid & 28 & 199 & 3 & 36 & 0 & 29 & 0 & 0 & 295 \\
\hline Ain El Hadjel & Ain El Hadjel & 2525 & 170 & 20 & 27 & 0 & 9 & 4 & 1 & 2756 \\
\hline Sidi Aissa & Sidi Aissa & 39 & 4 & 0 & 0 & 0 & 0 & 0 & 0 & 43 \\
\hline Ain El Melh & Ain El Melh & 13 & 0 & 0 & 0 & 0 & 0 & 0 & 0 & 13 \\
\hline \multirow[t]{2}{*}{ Boussaâda } & Boussaâda & 3658 & 4 & 6 & 6 & 210 & 912 & 0 & 0 & 4796 \\
\hline & Total & 7059 & 562 & 35 & 72 & 212 & 1637 & 7 & 1 & 9585 \\
\hline
\end{tabular}

Table 5. Identification of sandfly species belonging to the Sergentomyia genus collected during the survey.

\begin{tabular}{|c|c|c|c|c|c|c|c|c|c|c|}
\hline District & Station & S. minuta & S. schwetzi & S. fallax & S. antennata & S. dreyfussi & S. lewisi & S. christophersi & S. clydei & Total \\
\hline \multirow[t]{3}{*}{ M'Sila } & Nouara & 23 & 51 & 21 & 5 & 30 & 0 & 0 & 0 & 130 \\
\hline & Boukhmissa & 5 & 1 & 0 & 53 & 0 & 0 & 0 & 1 & 60 \\
\hline & Ouled Madhi & 40 & 67 & 355 & 263 & 1 & 0 & 0 & 0 & 726 \\
\hline \multirow[t]{2}{*}{ Chellal } & Khettouti Sed & 0 & 0 & 0 & 28 & 0 & 0 & 0 & 0 & 28 \\
\hline & Ait Ikhlef & 4 & 0 & 0 & 5 & 0 & 0 & 0 & 0 & 9 \\
\hline \multirow{3}{*}{ Magra } & Berhoum & 2 & 0 & 0 & 1 & 0 & 0 & 0 & 0 & 3 \\
\hline & Ain El Khadra & 0 & 1 & 0 & 4 & 0 & 0 & 0 & 0 & 5 \\
\hline & Dehahna & 1 & 0 & 0 & 12 & 0 & 0 & 0 & 0 & 13 \\
\hline $\begin{array}{c}\text { Hammam } \\
\text { Dalaa }\end{array}$ & El Guetaf & 0 & 1 & 0 & 17 & 0 & 0 & 0 & 0 & 18 \\
\hline $\begin{array}{l}\text { Ouled } \\
\text { Derradi }\end{array}$ & Maadid & 4 & 0 & 2 & 0 & 0 & 0 & 0 & 0 & 6 \\
\hline Ain El Hadjel & Ain El Hadjel & 16 & 1 & 0 & 0 & 0 & 0 & 0 & 0 & 17 \\
\hline Sidi Aissa & Sidi Aissa & 0 & 0 & 0 & 7 & 0 & 0 & 0 & 0 & 7 \\
\hline & Ain El Melh & 2 & 0 & 3 & 2 & 0 & 0 & 0 & 0 & 7 \\
\hline \multirow[t]{2}{*}{ Boussaâda } & Boussaâda & 59 & 0 & 8 & 6 & 15 & 3 & 1 & 0 & 92 \\
\hline & Total & 156 & 122 & 389 & 403 & 46 & 3 & 1 & 1 & 1121 \\
\hline
\end{tabular}

Within the M'Sila province, P. papatasi is highly prevalent, particularly in the districts with high CL incidence, $P$. longicuspis being abundant in districts where few cases of VL are recorded. The sandfly dynamics recorded in the province of M'Sila highlight a relation between sandfly density and the average temperature recorded. The sandfly population density reaches its first peak in June and a second in September (see Figure 9).

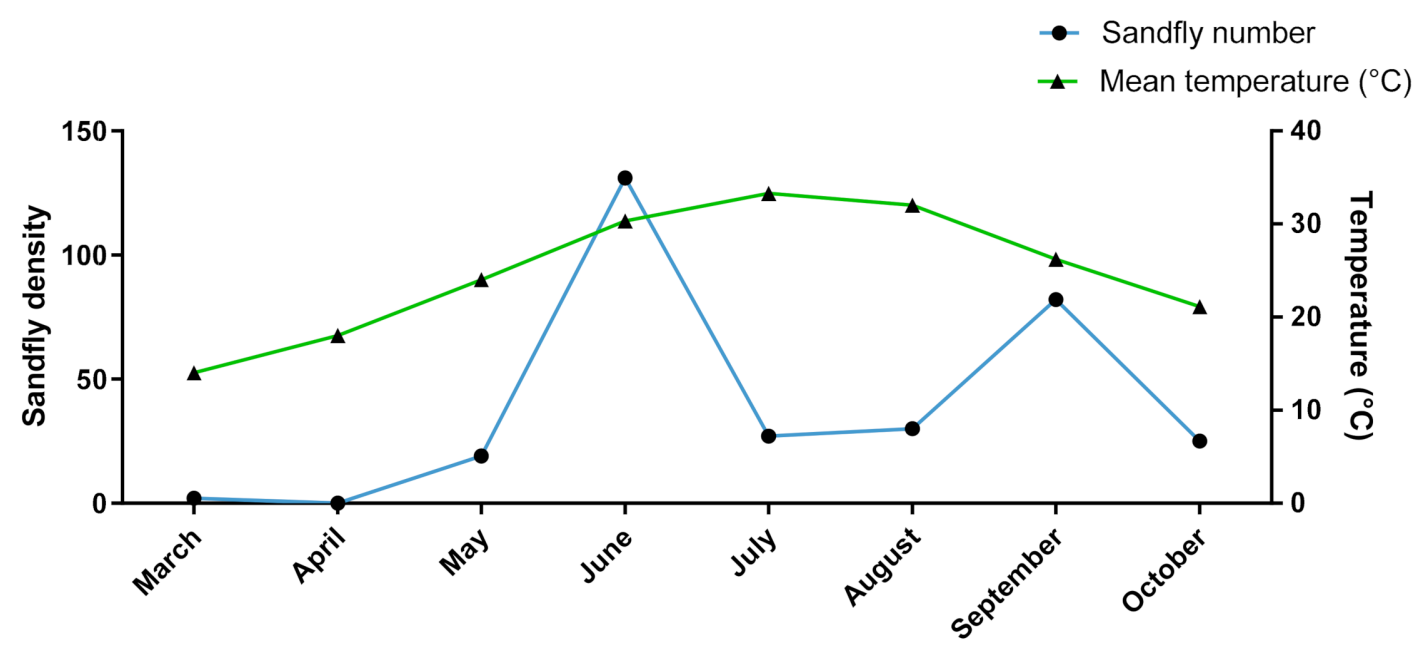

Sandfly temporal distribution

Figure 9. Seasonal dynamics of P. papatasi as recorded during the 2003/2004 transmission period. 
In Boussaâda, 12 species were identified; P. papatasi is highly abundant in this station (74.83\%), followed by P. longicuspis (18.65\%). Two species were detected for the first time in this region, P. chabaudi (4.29\%) and S. lewisi (0.06\%). In the district of M'Sila, the specimens collected belonged to 12 species. The Phlebotomus genus represents $86.78 \%$ of the total sample, and P. longicuspis (53.25\%) was the most prevalent. Notably, P. papatasi represented $33.84 \%$ of the specimens captured, and S. clydei was identified for the first time in this region. In Chellal, specimens belonging to 10 sandfly species were recorded. Sergentomyia were prevalent and represented $71.38 \%$, including S. fallax (46.53\%), S. antennata (38.79\%), S. schwetzi (8.78\%), and S. minuta (5.77\%). Phlebotomus papatasi represented $27.12 \%$ of sandflies captured in rodent burrows. In this district, P. perniciosus (3\%), P. longicuspis (1.31\%), P. alexandri and P. chabaudi (0.65\%) were also recorded. In Magra, 6 species were identified, with P. papatasi (53.85\%), P. perniciosus (19.23\%), and P. longicuspis (6.73\%) being the most frequently trapped. At Ain El Hadjel, 10 species were identified. Phlebotomus papatasi is the most abundant (91\%), followed by P. perniciosus (6\%). Four specimens of P. perfiliewi were collected for the first time in this arid region. A total of 7 species were identified at Ouled Derradj. Phlebotomus perniciosus is the most frequently identified (66\%), followed by P. sergenti (11.96\%), P. papatasi, and P. longicuspis (both $<10 \%$ ). In the districts of Sidi Aissa, Ain El Melh, and Hammam Delaa, a low number of sandflies were collected, with a large majority represented by P. papatasi (78\%).

\subsubsection{Biotope and Distribution of Sandflies in the Province of M'Sila}

Phlebotomus papatasi represents a non-negligible proportion of sandflies collected in the province of M'Sila (65.93\%). Indeed, this species is predominant in the stations of Ain El Hadjel (91\%), Sidi Aissa (78\%), Boussaâda and Ait Ikhlef (75\%), Berhoum (69.70\%), Ain El Melh (65\%), Khettouti Sed El Djir (63.41\%), Ain El Khadra (54.55\%), Dehahna (45\%), El Guetaf (43.75\%), Boukhmissa (42.2\%). P. papatasi is less frequent in Nouara $(27.6 \%)$, Ouled Madhi (19.6\%), and Ouled Derradj (9.3\%). On the other hand, P. longicuspis was relatively abundant in two stations; the garden areas with apricot trees in Nouara (51.82\%) and the palm grove of Boussaâda (19\%), which both are irrigated. Phlebotomus perniciosus is abundant in Ouled Derradj (66.11\%), Dehahna (23.33\%), and Berhoum (18.18\%). These three species represent $86.48 \%$ of all specimens collected. Two axes of the principal component analysis were retained (F1 and F2) since their calculated eigenvalues are close to 1 (Figure 10, upper panel).

The factorial plane displays that P. papatasi is the main contributor of the F1 inertia, and its abundance correlates with arid steppe, plains, and foothills, and less frequently with mountains (9.3\%). Steppes offer optimal ecological conditions for this species [7,24,38,39]. Phlebotomus perniciosus and P. longicuspis are the main contributors to the axis 2 inertia. A third group encompasses other sandfly species that, for the majority, are not of medical importance (Figure 10, lower panel).

\subsection{Survey of the Reservoir Hosts of Cutaneous Leishmaniasis}

More than 445 wild rodents belonging to 5 families, 7 genera, and 9 species were collected during the study (Table 2). Gerbils are abundant in the plains and the Chott (Table 2). Ctenodactylus gundi (Ctenodactylidae) is frequent in the Rocky Mountains of Boussaâda and Ain Farez (Daïra of Ain el melh), located $30 \mathrm{~km}$ south-east of Boussaâda city. Psammomys obesus and Meriones shawi often overlap in terms of territories. Psammomys obesus was trapped frequently in the steppe where Chenopodiaceae develop, the Chellal region, and the road shoulders along the Sebkha (around the Chott). This rodent species was also trapped at the piedmont of Jebel Choukchot's mountains near Sidi Aissa and in peripheral areas of M'Sila. Like M. shawi, it settled on the slopes at the edge of cereal fields. It is also abundant in orchards and agricultural areas. It was captured near the salt-lake (Sebkha) of M'Sila, in the countryside and its suburbs. Molecular diagnosis by PCR-RFLP revealed the infection by Leishmania in only two species, P. obesus, and M. shawi. Among the 186 P. obesus and the $37 \mathrm{M}$. shawi collected during the survey, $29.57 \%$ and $27 \%$ were positive 
for Leishmania DNA, respectively (Table 6). The 21 isolates of Leishmania from rodents $(P$. obesus $=17$, M. shawi $=4$ ) were identified as L. major MON-25 (see above).
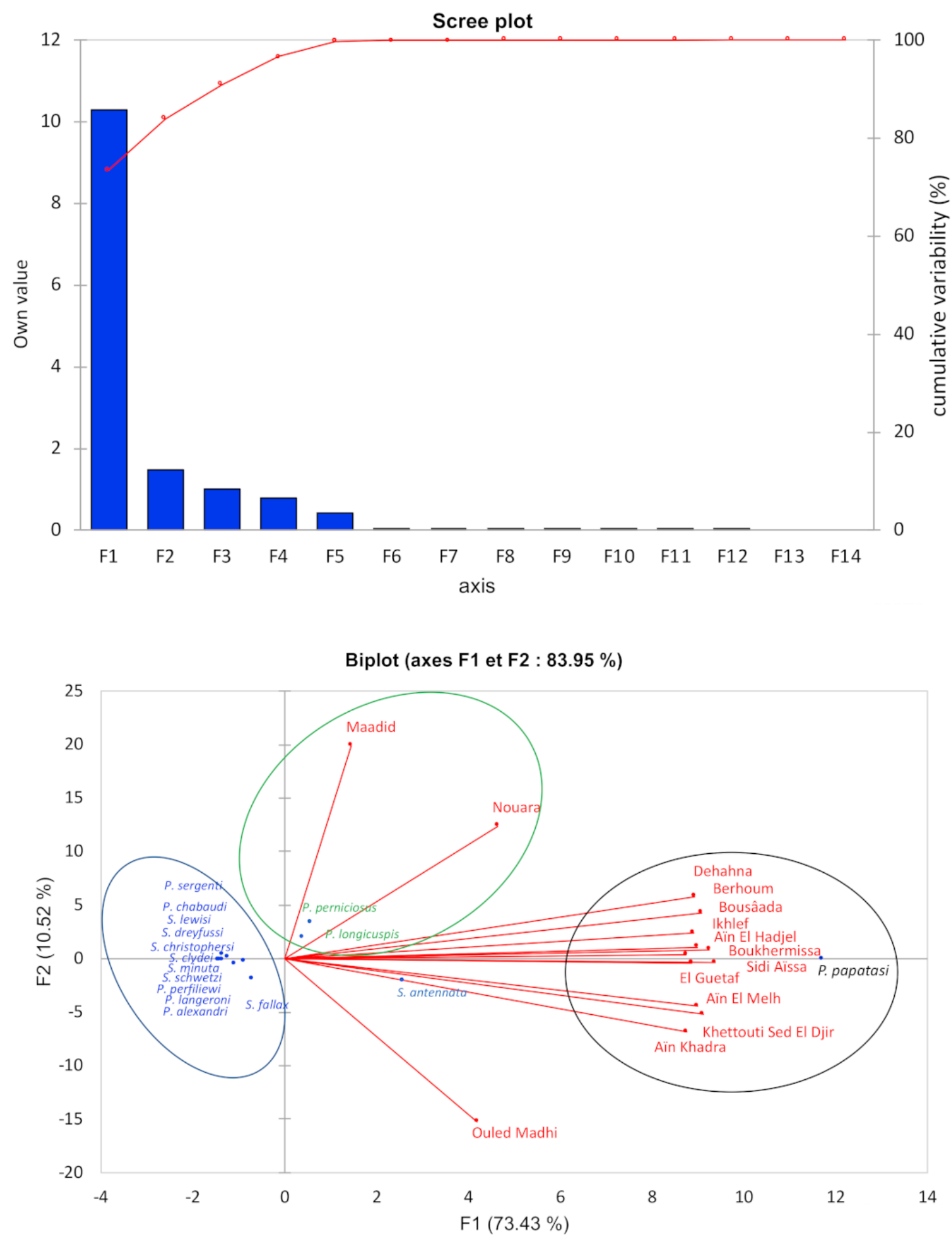

Figure 10. PCA analysis of sandfly species abundance in the districts belonging to the M'Sila province, according to the biotopes. Upper panel: calculated eigen values, Lower panel: representation of the biplot (F1 and F2 axes) analysis. 
Table 6. The infection rate of rodent samples as recorded by parasitological and molecular methods.

\begin{tabular}{|c|c|c|c|c|c|c|c|}
\hline District & Family & Genus/Species & Year & N Inv & $\mathbf{N}$ Inf & $\begin{array}{c}\text { Infestation Rate } \\
(\%)\end{array}$ & CI \\
\hline \multirow{6}{*}{$\begin{array}{c}\text { Chellal, Sidi Aissa, } \\
\text { other }\end{array}$} & \multirow{6}{*}{ Gerbillidae } & \multirow{6}{*}{ Psamomys obesus } & 1996 & - & - & - & \\
\hline & & & 2003 & 10 & 7 & 70 & [38.01-91.74] \\
\hline & & & 2004 & 30 & 5 & 16.66 & [6.37-33.15] \\
\hline & & & 2007 & - & - & - & \\
\hline & & & 2010 & 144 & 43 & 29.86 & [22.81-36.34] \\
\hline & & & 2018 & 12 & & & \\
\hline \multirow{9}{*}{$\begin{array}{c}\text { M'Sila, Sidi Aissa, } \\
\text { Magra, } \\
\text { Ain-El-Hadjel }\end{array}$} & \multirow{9}{*}{ Gerbillidae } & \multirow{9}{*}{ Meriones shawi } & Total & 186 & 55 & 29.57 & [23.34-36.43] \\
\hline & & & 1996 & - & - & & \\
\hline & & & 2000 & - & - & & \\
\hline & & & 2004 & 10 & 3 & 30 & [8.26-61.99] \\
\hline & & & 2008 & 20 & 6 & 30 & [13.16-52.28] \\
\hline & & & 2009 & - & - & & \\
\hline & & & 2012 & 6 & 1 & 16.66 & [0.83-59.09] \\
\hline & & & 2018 & 1 & & & \\
\hline & & & Total & 37 & 10 & 27.02 & [14.62-42.91] \\
\hline
\end{tabular}

CI: Confidence Interval.

\section{Discussion}

\subsection{Epidemiology of Leishmaniases in Algeria and M'Sila}

In Algeria, the first case of human CL was described in 1860 by Hamel in the former focus of Biskra [9] and 1924 in M'Sila [10]. The disease evolved slowly until the early 1980 s when outbreaks occurred suddenly in M'Sila, which is very close to Biskra. Since then, the disease has become a real public health problem, and its incidence has increased significantly in the recent decades [4,40]. After 34 years (1982-2017), more than a quarter of a million cases were recorded in all the country (252,659 cases), which equals an incidence of 1372 cases /100,000 inhabitants. Five provinces are highly endemic for CL, with more than 10,000 cases recorded between 1982 and 2017. Three are located in the west of the country and are adjacent to Biskra (Batna, M'Sila, and El Oued). M'Sila and its seven neighboring provinces account for $74.5 \%$ of the total CL cases reported in Algeria during the 34 years of our study. M'Sila and Biskra alone account for $37.22 \%$ of the recorded cases during these three decades. A Dunnett's statistical analysis discloses no significant differences in terms of incidence between these two provinces. The temporal dynamics of the CL case number follow that of M'Sila, showing the endemic-epidemic profile of the disease with a high proportion of cases in the direct neighborhood of patients (56.1\%).

\subsection{Leishmania Species and Clinical Presentation in M'Sila}

Parasite identifications carried out during our prospective and retrospective surveys ( 87 by MLEE, 42 by PCR-RFLP) confirmed L. major as the etiological agent of CL in the M'Sila region and are in accordance with previous studies [3,12,41]. The most common zymodem in Algeria (MON-25) [12,41] was the sole identified. However, variability was recorded for three enzymatic systems, G6PD, PGM, and ME, in some isolates from Boussaâda, Sidi Aissa, and M'Sila. Leishmania major MON-269 as a causative agent of CL was previously reported in Algeria [41]. This zymodem differs from MON-25 by a single enzyme system (PGD 122/94) and could correspond to a recent mutation or a posttranslational modification [42]. The combination of four diagnostic methods (microscopy, NNN culture, ITS1-PCR, and RT-PCR) allowed diagnosis confirmation of a maximum number of cases among the suspected CL patients, resulting in a more accurate clinical description of the disease. As reported [31,43], RT-PCR was the most sensitive (100\%) technique. On the other hand, the high sensitivity of cultures $(72.9 \%)$ is related to the adaptation of L. major to the NNN medium [27]. The clinical appearance is characterized by a predominance of childhood infection and multiple lesions $(61.4 \%)$, preferentially 
localized to the limbs (70.4\%) [44]. Children of less than or equal to 15 years ( $76.1 \%$ of cases) considered as "naive" are likely to be the most susceptible to L. major infection $[45,46]$.

Otherwise, M'Sila does not fall into the group of provinces where VL is endemic; therefore, the identification of $L$. infantum in dogs and humans requires further studies to delineate the endemic occurrence of the transmission cycle.

\subsection{Sandfly Diversity and Dynamics in Algeria and M'Sila}

Out of the 24 species reported in Algeria [24,47,48], 16 were identified during this study, mostly in sympatry in the various districts investigated. The comparable richness in sandfly fauna was reported in the north/north-eastern and middle eastern regions of Algeria [49-51]. Our study enriched the sandfly entomofauna of M'Sila [52] with 6 new species, P. chabaudi, P. langeroni, P. perfiliewi, S. clydei, S. schwetzi, and S. lewisi. The high proportion (65.93\%) of P. papatasi in surveys performed during 2003-2004 and 2018 and reported by Boudrissa in M'Sila and the neighboring provinces [4] indicates that sandfly richness might not have changed over time in this area. Likewise, P. papatasi being the proven vector of $L$. major, zoonotic CL incidence, is high in this area [15,53].

Interestingly, some identified sandfly species with high densities in some districts, such as P. perniciosus and P. longicuspis, are suspected or proven vectors for visceral leishmaniasis. The sandfly seasonal dynamics revealed a bell-shaped density curve with a broad peak encompassing the July-September period and between early October to late May. The season for leishmaniasis transmission risk took place from early June through the end of September when maximal density is achieved. This kind of bell-shaped density curve was described for sandflies in the Mediterranean area [54]. During this period, the second and third generations of sandflies are more abundant, increasing the infection risk [53]. The ZCL seasonal dynamic is under minimal temperature control and presents a 2-month lag between the reported infection date and the presumed date of CL lesion onset $[55,56]$.

\subsection{Ecology, Diversity, and Medical Importance of Sandflies in M'Sila}

The 5 stations analyzed with PCA revealed a predominance of $P$. papatasi in stations above $300 \mathrm{~m}$ of elevation, plains, and piedmonts and coincided with the ZCL foci of M'Sila. In these areas, steppes constitute the optimal ecological niche for P. papatasi. Phlebotomus papatasi can also be present at a higher altitude, up to $1000 \mathrm{~m}$, like in Maadid, where it accounted for $9.30 \%$ of the total specimen trapped. In lowland rural areas, P. papatasi reach up to 91\% (Ain El Hadjel, Sidi Aissa, and Boussaâda). The low sanitation level would favor the presence of manure and organic matter that, along with high humidity, are adequate for sandfly breeding [57]. Phlebotomus perniciosus and P. longicuspis are abundant mainly in the piedmont area of Nouara (M'Sila) and the mountain of Maadid (Ouled derradj), respectively. Phlebotomus longicuspis is abundant in humid peri-urban regions, like in Nouara, or Boussaâda palm grove, representing $51.82 \%$ and $18.65 \%$ of the total trapped sandflies, respectively. It is a suspected L. infantum vector in the arid zones of Morocco and Tunisia [58,59]. Leishmania infantum has been detected in P. longicuspis in Algeria [60]. During our survey in 2018, two autochthonous VL cases and one canine case were detected in Maarif (a few kilometers from Boussaâda city). However, the potential vectorial role of $P$. longiscupis for L. infantum requires to be proved more thoroughly in M'Sila. Only seven specimens of $P$. perfiliewi, a proven vector of CL caused by L. infantum in Algeria [61,62] and Tunisia [63], and of VL in Algeria [64], were captured during our survey. Common in the humid and subhumid areas, this sandfly was collected in the highlands' arid region, where conditions might not be optimal for this species [24]. This species is abundant in the semi-arid bioclimatic stages, like in Constantine [50,65]. Specimen of the paraphlebotomus genus were less frequently trapped. Phlebotomus sergenti represented $0.68 \%$ of the total specimen, but it reached up to $12 \%$ in the Maadid station in Ouled Derradj. In Algeria, this species is mainly encountered in the south of the country in the Saharan Atlas' foothills, the pre-Saharan steppes, and the Tell regions [24]. It was found in crevices of walls, rodent burrows, and rocky areas [24]. It is the proven vector of 
L. tropica [66] in the Middle East and probably of L. killicki (syn: L. tropica) in the Maghreb countries [67]. Leishmania killicki has been identified in many CL cases in Ghardaia in the center of Algeria [68]. Phlebotomus chabaudi was observed in the Boussaâda palm grove, and the Chellal region (Ouled Madhi). Since its description in Tunisia [23], the presence of this species is documented in Ghardaïa in Algeria [69] and Morocco [70]. The presence of $P$. chabaudi in the biotopes of Ctenodactylus gundi (rocky biotopes) would make them a potential vector of L. tropica. Phlebotomus (Par). Alexandri, collected in the district of Ain El Hadjel, is considered as a ZCL vector in the former USSR and Iran [71,72]. Also, in this district a single specimen of Phlebotomus (Lar) langeroni was collected. It is considered as a vector of L. infantum, responsible for sporadic CL in Northern Tunisia [73] and of VL in Egypt [74,75]. It is particularly abundant in rocky and dry biotopes where Ctenodactylus gundi and reptiles roost [24].

\subsection{Rodents and Reservoirs in the M'Sila Province}

In Algeria, the endemicity of the ZCL is linked to a regular epidemiological cycle maintained by $P$. obesus, whose populations are geographically restricted. In contrast, epidemic outbreaks correlate with the proliferation of $M$. shawi and food abundance during rainy years. The surveys have made possible an update of mammalian fauna inventory and a more accurate spatial and micro-zonal distribution of rodents playing a role in ZCL transmission. Several ecological niches were identified, and nine rodent species were inventoried. This number does not reflect the rodent fauna richness in this region since the inventory performed in 1991 by Kowalski and Rzebik-Kowalska [76] reported 19 rodent species in the Hodna basin. During our survey, only P. obesus and M. shawi were found infected by L. major MON-25 (Table 2). The presence of L. major in M. shawi trapped in Sidi Aissa (1996), and Ain El Khadra (2000) (Table 2) represent the first report of such events in the M'Sila province. The molecular diagnosis detected L. major in $29.57 \%$ of P. obesus and $27 \%$ of $M$. shazwi trapped. This confirms the primary reservoir's role of these two species in the province of M'Sila.

Interestingly, in a previous study, a Leishmania isolates from Meriones spp. was categorized as non-susceptible (S-) toward trivalent and pentavalent antimony [6,77]. Further experiments are required to address the risk of chemotherapeutic failure in link with the transmission of such variants.

\section{Conclusions}

Zoonotic CL caused by L. major is highly prevalent in the M'Sila region for more than 30 years, with an average of around 3000 cases per year. This focus is characterized by an arid bioclimate, a high density of $P$. papatasi sandflies, and a high Leishmania infection rate of Psammomys obesus and Meriones shawi rodents. The clinical profile of the disease is similar to that described in other North African countries, CL being most frequently encountered mainly in childhood and presenting as multiple lesions preferentially localized on the limbs. Identifying ZCL risk factors in M'Sila could allow more efficient control of the disease.

Author Contributions: Conceptualization, R.B., Z.H., D.S., and K.A.; methodology, R.B., A.B. (Abdelkarim Boudrissa), M.B.A. and S.C.B.; validation, Z.H., K.A. and D.S.; formal Analysis, R.B., K.C. and W.A.; investigation, R.B., A.B. (Abdelkarim Boudrissa), S.B. and Z.H.; resources, R.B. and A.B. (Abdelkarim Boudrissa); data curation, R.B. and D.S.; writing-original draft preparation, R.B., D.S. and K.A.; writing-review and editing, R.B. and D.S.; project administration, Z.H., A.B. (Aïda Bouratbine) and G.F.S. All authors have read and agreed to the published version of the manuscript.

Funding: *LeiSHield-MATI project "A multi-disciplinary international effort to identify clinical, molecular and social factors impacting cutaneous leishmaniasis" H2020-MSCA-RISE-2017-778298LeiSHield-MATI. *Pasteur institute of Algeria. *Pasteur Institute of Tunis and the Tunisian Ministry of Scientific Research and Higher Education, in the frame of the research lab LR-20-IPT-06 "Medical Parasitology, Biotechnology and Biomolecules". *IRD funded the APC.

Institutional Review Board Statement: Not applicable. 
Informed Consent Statement: Informed consent was obtained from all subjects involved in the study.

Data Availability Statement: Not applicable.

Acknowledgments: Adel Rhim, Olfa Souissi, Ines BenSghaier and Najet Zallagua from LR 20-IPT-06 and Bencherifa Souad, Lazhari Bouiba, Ihcen Kerachi, Ghania Mezai for their technical support, as well as the members of the annex of the Pasteur Institute of M'Sila and the SEMEP of Bousaâda for their collaboration and their invaluable contributions.

Conflicts of Interest: The authors declare no conflict of interest.

\section{References}

1. Alvar, J.; Vélez, I.D.; Bern, C.; Herrero, M.; Desjeux, P.; Cano, J.; Jannin, J.; den Boer, M.; WHO Leishmaniasis Control Team. Leishmaniasis Worldwide and Global Estimates of Its Incidence. PLoS ONE 2012, 7, e35671. [CrossRef] [PubMed]

2. Belazzoug, S. Outbreak of cutaneous leishmaniasis in the M'Sila region (Algeria). Bulletin de la Societe de Pathologie Exotique et de ses Filiales 1982, 75, 497-504. [PubMed]

3. Rioux, J.A.; Lanotte, G.; Petter, F.; Dereure, J.; Akalay, O.; Pratlong, F.; Velez, I.D.; Fikri, N.B.; Maazoun, R.; Deniau, M. Les leishmanioses Cutanées du Bassin Méditerranéen Occidental. De L'identification Enzymatique à L'analyse éco-Epidémiologique. L'exemple de Trois 'Foyers', Tunisien, Marocain et Français; Colloque International CNRS/INSERM, Institut Méditerranéen d'Etudes Epidemiologiques et Ecologiques: Montpellier, France, 1986; pp. 365-395.

4. Boudrissa, A.; Cherif, K.; Kherrachi, I.; Benbetka, S.; Bouiba, L.; Boubidi, S.C.; Benikhlef, R.; Arrar, L.; Hamrioui, B.; Harrat, Z. Spread of Leishmania major to the north of Algeria. Bulletin de la Societe de Pathologie Exotique (1990) 2012, 105, 30-35. [CrossRef] [PubMed]

5. Aoun, K.; Bouratbine, A. Cutaneous Leishmaniasis in North Africa: A review. Parasite 2014, 21, 14. [CrossRef] [PubMed]

6. Eddaikra, N.; Ait-Oudhia, K.; Kherrachi, I.; Oury, B.; Moulti-Mati, F.; Benikhlef, R.; Harrat, Z.; Sereno, D. Antimony susceptibility of Leishmania isolates collected over a 30-year period in Algeria. PLoS Negl. Trop. Dis. 2018, 12, e0006310. [CrossRef]

7. Kholoud, K.; Bounoua, L.; Sereno, D.; El Hidan, M.; Messouli, M. Emerging and Re-Emerging Leishmaniases in the Mediterranean Area: What Can Be Learned from a Retrospective Review Analysis of the Situation in Morocco during 1990 to 2010 ? Microorganisms 2020, 8, 1511. [CrossRef]

8. INSP. Relevé Epidémiologique Mensuel. Available online: http://insp.dz/index.php/Non-categorise/rem.html (accessed on 28 May 2020).

9. Hamel, H. Étude Comparée des Boutons d'Alep et de Biskra, History of Natural Sciences and Medicine; Medical Library. Seidel collection; Hachette Livre: Paris, France, 1860; p. 31.

10. Parrot, L.; Foley, H. Epidemiology of Oriental Sore in Algeria. Bulletin de la Societe de Pathologie Exotique (1990) 1925, $18,639-641$.

11. INSP. Situation Epidémiologique de L'année 2010 sur la Base des cas Déclarés à l'INSP. Available online: http:/ / www.insp.dz/ images/PDF/Epidemio/rem_2010.pdf (accessed on 28 May 2020).

12. Harrat, Z.; Pratlong, F.; Belazzoug, S.; Dereure, J.; Deniau, M.; Rioux, J.A.; Belkaid, M.; Dedet, J.P. Leishmania infantum and L. major in Algeria. Trans. R. Soc. Trop. Med. Hyg. 1996, 90, 625-629. [CrossRef]

13. Belazzoug, S. Isolation of Leishmania major Yakimoff \& Schokhor, 1914 from Psammomys obesus Gretzschmar, 1828 (Rodentia: Gerbillidae) in Algeria. Trans. R. Soc. Trop. Med. Hyg. 1983, 77, 876. [CrossRef]

14. Belazzoug, S. Découverte d'un Meriones shawi (Rongeur, Gerbillidé) naturellement infesté par Leishmania dans le nouveau foyer de leishmaniose cutanée de Ksar Chellala (Algérie). Bulletin de la Société de Pathologie Exotique 1986, 79, 630-633.

15. Izri, M.; Belazzoug, S.; Pratlong, F.; Rioux, J.A. Isolement de Leishmania major chez Phlebotomus papatasi à Biskra (Algérie): Fin d'une épopée écoépidémiologique. Annales de Parasitologie Humaine et Comparee 1992, 67, 31-32. [CrossRef]

16. Mili, M.; Boutabba, H.; Boutabba, S.-D. La nature urbaine: Dégradation quantitative et qualitative des espaces verts urbains, cas de la ville steppique de M'Sila, Algérie. urbe. Revista Brasileira de Gestão Urbana 2019, 11, 11. [CrossRef]

17. Despois, J. Le Hodna (Algérie). Revue de géographie alpine. Publications de la Faculté des Lettres d'Alger; Presses Universitaires de France: Paris, France, 1953; p. 409.

18. INSP. Situation Epidémiologique de L'année 2005 sur la Base des cas Déclarés à l'INSP. Available online: http:/ /insp.dz/images / PDF/Epidemio/rem_2005.pdf (accessed on 28 May 2020).

19. Boudjemline, F.; Semar, A. Assessment and mapping of desertification sensitivity with MEDALUS model and GIS - Case study: Basin of Hodna, Algeria. J. Water Land Dev. 2018, 36, 17-26. [CrossRef]

20. Infoclimat. Available online: https://www.infoclimat.fr/observations-meteo/temps-reel/m-sila/60467.html (accessed on 28 July 2020).

21. Rioux, J.-A.; Golvan, Y.-J.; Croset, H.; Houin, R.; Juminer, B.; Bain, O.; Tour, S. Ecologie des Leishmanioses dans le sud de la France. 1. - Les Phlébotomes. Annales de Parasitologie Humaine et Comparée 1967, 42, 561-603. [CrossRef]

22. Abonnenc, E. Les Phlébotomes de la Région Ethiopienne (Diptera, Psychodidae); ORSTOM: Paris, France, 1972; Volume 55, p. 289.

23. Croset, H.; Rioux, J.A.; Maistre, M.; Bayar, N. Les Phlébotomes de Tunisie (Diptera, Phlebotomidae). Mise au point systématique, chorologique et éthologique. Ann. Parasitol. Hum. Comp. 1978, 53, 711-749. [CrossRef] 
24. Dedet, J.P.; Addadi, K.; Belazzoug, S. Les phlébotomes (Diptera, Psychodidae) d'Algérie. Cahiers-ORSTOM. Entomologie Médicale et Parasitologie 1984, 22, 99-127.

25. Bernard, J. Clef de détermination des rongeurs de Tunisie. Arch. Inst. Pasteur Tunis 1970, 47, $265-307$.

26. Berrebi, J. The Cultivation of Leishmania. Arch. Inst. Pasteur Tunis. 1936, 25, 89-141.

27. Chouihi, E.; Amri, F.; Bouslimi, N.; Siala, E.; Selmi, K.; Zallagua, N.; Abdallah, R.B.; Bouratbine, A.; Aoun, K. Les cultures sur milieu NNN dans le diagnostic biologique des leishmanioses Cultures on NNN medium for the diagnosis of leishmaniasis. Pathol. Biol. 2009, 57, 219-224. [CrossRef]

28. Schonian, G.; Nasereddin, A.; Dinse, N.; Schweynoch, C.; Schallig, H.D.; Presber, W.; Jaffe, C.L. PCR diagnosis and characterization of Leishmania in local and imported clinical samples. Diagn. Microbiol. Infect. Dis. 2003, 47, 349-358. [CrossRef]

29. World Health Organization (WHO). Manuel Pour la Prise en Charge de la Leishmaniose Cutanée dans la Région OMS de la Méditerranée Orientale; WHO Regional Publications, Eastern Mediterranean Series; WHO: Geneve, Switzerland, 2014; N35: 978-92-9021-996-5.

30. Belkaid, P.M.; Harrat, Z.; Hamrioui, B.; Thellier, M.; Datry, A.; Danis, M. A simple media for isolation and culture of leishmania. Bulletin de la Societe de Pathologie Exotique (1990) 1996, 89, 276-277.

31. Mary, C.; Faraut, F.; Lascombe, L.; Dumon, H. Quantification of Leishmania infantum DNA by a Real-Time PCR Assay with High Sensitivity. J. Clin. Microbiol. 2004, 42, 5249-5255. [CrossRef] [PubMed]

32. Staden Package Home. Available online: http:/ / staden.sourceforge.net (accessed on 15 December 2020).

33. Molecular Evolutionary Genetics Analysis. Available online: www.megasoftware.net (accessed on 20 July 2019).

34. Basic Local Alignment Search Tool. Available online: https://blast.ncbi.nlm.nih.gov/Blast.cgi (accessed on 20 July 2019 ).

35. Gouy, M.; Guindon, S.; Gascuel, O. SeaView Version 4: A Multiplatform Graphical User Interface for Sequence Alignment and Phylogenetic Tree Building. Mol. Biol. Evol. 2009, 27, 221-224. [CrossRef] [PubMed]

36. Dereeper, A.; Guignon, V.; Blanc, G.; Audic, S.; Buffet, S.; Chevenet, F.; Dufayard, J.-F.; Guindon, S.; Lefort, V.; Lescot, M.; et al. Phylogeny.fr: Robust phylogenetic analysis for the non-specialist. Nucleic Acids Res. 2008, 36, W465-W469. [CrossRef]

37. Rioux, J.A.; Lanotte, G.; Serres, E.; Pratlong, F.; Bastien, P.; Perieres, J. Taxonomy ofLeishmania.Use of isoenzymes. Suggestions for a new classification. Annales de Parasitologie Humaine et Comparée 1990, 65, 111-125. [CrossRef]

38. Gherbi, R.; Bounechada, M.; Latrofa, M.S.; Annoscia, G.; Tarallo, V.D.; Dantas-Torres, F.; Otranto, D. Phlebotomine sand flies and Leishmania species in a focus of cutaneous leishmaniasis in Algeria. PLOS Negl. Trop. Dis. 2020, 14, e0008024. [CrossRef]

39. Guernaoui, S.; Hamarsheh, O.; Garcia, D.; Fontenille, D.; Sereno, D. Population Genetics of Phlebotomus papatasi from Endemic and Nonendemic Areas for Zoonotic Cutaneous Leishmaniasis in Morocco, as Revealed by Cytochrome Oxidase Gene Subunit I Sequencing. Microorganisms 2020, 8, 1010. [CrossRef]

40. Randa, G.; Samir, Z.; Hamid, B. Association between climatic changes and leishmaniasis incidence in Biskra district, Algeria. J. Entomol. Zool. Stud. 2017, 5, 43-49.

41. Pratlong, F.; Dereure, J.; Ravel, C.; Lami, P.; Balard, Y.; Serres, G.; Lanotte, G.; Rioux, J.-A.; Dedet, J.-P. Geographical distribution and epidemiological features of Old World cutaneous leishmaniasis foci, based on the isoenzyme analysis of 1048 strains. Trop. Med. Int. Health 2009, 14, 1071-1085. [CrossRef]

42. Mauricio, I.L.; Yeo, M.; Baghaei, M.; Doto, D.; Pratlong, F.; Zemanova, E.; Dedet, J.-P.; Lukes, J.; Miles, M.A. Towards multilocus sequence typing of the Leishmania donovani complex: Resolving genotypes and haplotypes for five polymorphic metabolic enzymes (ASAT, GPI, NH1, NH2, PGD). Int. J. Parasitol. 2006, 36, 757-769. [CrossRef]

43. Mihoubi, I.; Monbrison, F.D.; Romeuf, N.; Moulahem, T.; Picot, S. Diagnostic delocalise par PCR temps reel de la leishmaniose cutanee sevissant dans le foyer de Constantine (Algerie). Médecine Trop. 2006, 66, 39-43.

44. Aoun, K.; Ben Abda, I.; Bousslimi, N.; Bettaieb, J.; Siala, E.; Ben Abdallah, R.; Benmously, R.; Bouratbine, A. Comparative characterization of skin lesions observed in the three endemic varieties of cutaneous leishmaniasis in Tunisia. Annales de Dermatologie et de Venereologie 2012, 139, 452-458. [CrossRef]

45. Reithinger, R.; Dujardin, J.-C.; Louzir, H.; Pirmez, C.; Alexander, B.; Brooker, S. Cutaneous leishmaniasis. Lancet Infect. Dis. 2007, 7, 581-596. [CrossRef]

46. Chamakh-Ayari, R.; Chenik, M.; Chakroun, A.S.; Bahi-Jaber, N.; Aoun, K.; Meddeb-Garnaoui, A. Leishmania major large RAB GTPase is highly immunogenic in individuals immune to cutaneous and visceral leishmaniasis. Parasites Vectors 2017, 10, 1-11. [CrossRef]

47. Berchi, S.; Rioux, J.A.; Belmonte, A.; Russo, J. Un phlébotome nouveau pour l'Algérie, Phlebotomus (Paraphlebotomus) kazeruni. Annales de Parasitologie Humaine et Comparee 1986, 61, 507-508. [CrossRef]

48. Belazzoug, S. The sandflies of Algeria. Parassitologia 1991, 33, 85-87.

49. Zeroual, S.; Gaouaoui, R.; Boudjlida, H. Diversity and occurrence of phlebotomine sand flies (Diptera: Psychodidae) in the area of Biskra (Middle Eastern of Algeria). J. Entomol. Zool. Stud. 2016, 4, 890-895.

50. Ramdane, E.; Berchi, S.; Louad, K. Les phlébotomes (Diptera, Pshycodidae), vecteurs d'agents pathogènes responsables de la leishmaniose humaine dans la région de Constantine (Algérie). Entomofauna 2018, 39, 537-555.

51. Boukraa, S.; Boubidi, S.; Zimmer, J.-Y.; Francis, F.; Haubruge, E.; Alibenali-Lounaci, Z.; Doumandji, S. Surveillance des populations de phlébotomes (Diptera: Psychodidae), vecteurs des agents responsables des leishmanioses dans la région du M'Zab-Ghardaïa (Algérie). Faun. Entomol. 2011, 63, 97-101.

52. Belazzoug, S.; Mahzoul, D.; Rioux, J.A. The phlebotomus sandflies (Diptera, Psychodidae) of M'Sila and Bou-Saada. Archives de l'Institut Pasteur d'Algerie. Institut Pasteur d'Algerie 1986, 55, 117-124. 
53. Chelbi, I.; Derbali, M.; Al-Ahmadi, Z.; Zaafouri, B.; El Fahem, A.; Zhioua, E. Phenology of Phlebotomus papatasi (Diptera: Psychodidae) relative to the seasonal prevalence of zoonotic cutaneous leishmaniasis in central Tunisia. J. Med Entomol. 2007, 44, 385-388. [CrossRef] [PubMed]

54. Alten, B.; Maia, C.; Afonso, M.O.; Campino, L.; Jiménez, M.; González, E.; Molina, R.; Bañuls, A.L.; Prudhomme, J.; Vergnes, B.; et al. Seasonal Dynamics of Phlebotomine Sand Fly Species Proven Vectors of Mediterranean Leishmaniasis Caused by Leishmania infantum. PLOS Negl. Trop. Dis. 2016, 10, e0004458. [CrossRef] [PubMed]

55. Bounoua, L.; Kahime, K.; Houti, L.; Blakey, T.; Ebi, K.L.; Zhang, P.; Imhoff, M.L.; Thome, K.J.; Dudek, C.; Sahabi, S.A.; et al. Linking Climate to Incidence of Zoonotic Cutaneous Leishmaniasis (Lmajor) in Pre-Saharan North Africa. Int. J. Environ. Res. Public Health 2013, 10, 3172-3191. [CrossRef] [PubMed]

56. Kholoud, K.; Denis, S.; Lahouari, B.; El Hidan, M.A.; Souad, B. Management of Leishmaniases in the Era of Climate Change in Morocco. Int. J. Environ. Res. Public Health 2018, 15, 1542. [CrossRef] [PubMed]

57. Parrot, L. Les espèces algériennes du genre Phlebotomus (Psychodidae). Butt. Soc. Hist. nal. Afr. N. 1935, $26,23-27$.

58. Dereure, J.; Pratlong, F.; Lanotte, G.; Rioux, J.A. La leishmaniose viscérale autochtone au Maroc méridional. Leishmania. Taxonomie et phyllogenèse. Application éco-épidémiologiques. Coll. Int. CNRS/INSERM 1986, 37, 225.

59. Zhioua, E.; Kaabi, B.; Chelbi, I. Entomological investigations following the spread of visceral leishmaniasis in Tunisia. J. Vector Ecol. 2007, 32, 371-374. [CrossRef]

60. Berdjanebrouk, Z.; Charrel, R.N.; Bitam, I.; Hamrioui, B.; Izri, A. Record ofPhlebotomus (Transphlebotomus) mascittiiGrassi, 1908 andPhlebotomus (Larroussius) chadliiRioux, Juminer \& Gibily, 1966 female in Algeria. Parasite 2011, 18, 337-339. [CrossRef]

61. Belazzoug, S.; Lanotte, G.; Maazoun, R.; Pratlong, F.; Rioux, J.A. A new enzymatic variant of Leishmania infantum Nicolle, 1908, agent of cutaneous leishmaniasis in northern Algeria. Annales de Parasitologie Humaine et Comparee 1985, 60, 1-3. [CrossRef]

62. Izri, M.; Belazzoug, S. Phlebotomus (Larroussius) perfiliewi naturally infected with dermotropic Leishmania infantum at Tenes, Algeria. Trans. R. Soc. Trop. Med. Hyg. 1993, 87, 399. [CrossRef]

63. Kallel, K.; Haouas, N.; Pratlong, F.; Kaouech, E.; Belhadj, S.; Anane, S.; Dedet, J.P.; Babba, H.; Chaker, E. Cutaneous leishmaniasis caused by Leishmania infantum MON-24 in Tunisia: Extension of the focus to the center of the country. Bulletin de la Societe de Pathologie Exotique (1990) 2008, 101, 29-31.

64. Benikhlef, R.; Pratlong, F.; Harrat, Z.; Seridi, N.; Bendali-Braham, S. Leishmaniose viscérale infantile causée par Leishmania infantum zymodème MON-24 en Algérie. Bulletin de la Société de Pathologie Exotique 2001, 94, 14-16.

65. Moulahem, T.; Fendri, A.H.; Harrat, Z.; Benmezdad, A.; Aissaoui, K.; Ahraou, S.; Addadi, K. Phlebotomus of Constantine: Species captured in an urban apartment. Bulletin de la Société de Pathologie Exotique 1998, 91, 344-345.

66. Boubidi, S.; Benallal, K.E.; Boudrissa, A.; Bouiba, L.; Bouchareb, B.; Garni, R.; Bouratbine, A.; Ravel, C.; Dvorak, V.; Votypka, J.; et al. Phlebotomus sergenti (Parrot, 1917) identified as Leishmania killicki host in Ghardaïa, south Algeria. Microbes Infect. 2011, 13, 691-696. [CrossRef]

67. Tabbabi, A.; Aoun, K.; Rhim, A.; Bousslimi, N.; Bouratbine, A. First Report on Natural Infection of Phlebotomus sergenti with Leishmania Promastigotes in the Cutaneous Leishmaniasis Focus in Southeastern Tunisia. Am. J. Trop. Med. Hyg. 2011, 85, 646-647. [CrossRef]

68. Harrat, Z.; Boubidi, S.C.; Pratlong, F.; Benikhlef, R.; Selt, B.; Dedet, J.P.; Ravel, C.; Belkaid, M. Description of a dermatropic Leishmania close to L. killicki (Rioux, Lanotte \& Pratlong 1986) in Algeria. Trans. R. Soc. Trop. Med. Hyg. 2009, 103, 716-720. [CrossRef]

69. Rioux, J.-A.; Croset, H.; Guy, Y.; Maistre, M. Présence de Phlebotomus (Paraphlebotomus) chahaudi Croset, Abonnenc et Rioux, 1970 en Algérie. Annales de Parasitologie Humaine et Comparée 1970, 45, 875-880. [CrossRef]

70. Rioux, J.A.; Croset, H.; Leger, N.; Benmansour, N.; Soussi, M.C.; Maistre, M.; Jonquet, Y. Présence au Maroc de Phlebotomus bergeroti, Phlebotomus chabaudi, Phlebotomus chadlii et Sergentomyia christophersi. Annales de Parasitologie Humaine et Comparée 1975, 50, 493-506. [CrossRef]

71. Petriščeva, P.A. The natural focality of leishmaniasis in the USSR. Bull. World Health Organ. 1971, 44, 567-576.

72. Javadian, E.; Nadim, A. Studies on cutaneous leishmaniasis in Khuzestan, Iran. Part II. The status of sandflies. Bulletin de la Societe de Pathologie Exotique et de ses Filiales 1975, 68, 467-471.

73. Guerbouj, S.; Chemkhi, J.; Kaabi, B.; Rahali, A.; Ben Ismail, R.; Guizani, I. Natural infection of Phlebotomus (Larroussius) langeroni (Diptera: Psychodidae) with Leishmania infantum in Tunisia. Trans. R. Soc. Trop. Med. Hyg. 2007, 101, 372-377. [CrossRef] [PubMed]

74. Doha, S.; Shehata, M.G. Leishmania infantum MON-98 Isolated from Naturally Infected Phlebotomus langeroni (Diptera: Psychodidae) in El Agamy, Egypt. J. Med Entomol. 1992, 29, 891-893. [CrossRef] [PubMed]

75. El Sawaf, B.M.; Beier, J.C.; Hussein, S.M.; Kassem, H.A.; Satter, S.A. Phlebotomus langeroni: A potential vector of kala-azar in the Arab Republic of Egypt. Trans. R. Soc. Trop. Med. Hyg. 1984, 78, 421. [CrossRef]

76. Kowalski, K.; Rzebik-Kowalska, B. Mammals of Algeria. Polish Academy of Sciences, 1st ed.; Institut of Systematics and Evolution of Animals, Ossolineum: Wrocław, Poland, 1991; p. 370.

77. Sereno, D.; Harrat, Z.; Eddaikra, N. Meta-analysis and discussion on challenges to translate Leishmania drug resistance phenotyping into the clinic. Acta Trop. 2019, 191, 204-211. [CrossRef] 